\title{
G6pd Deficiency Does Not Affect the Cytosolic Glutathione or Thioredoxin Antioxidant Defense in Mouse Cochlea
}

\author{
Karessa White, ${ }^{1}$ Mi-Jung Kim, ${ }^{1}$ Dalian Ding, ${ }^{2}$ CChul Han, ${ }^{1}$ Hyo-Jin Park, ${ }^{1,3}$ Zaimary Meneses, ${ }^{1}$ Masaru Tanokura, ${ }^{4}$ \\ -Paul Linser, ${ }^{3}$ Richard Salvi, ${ }^{2}$ and ${ }^{1}$ Shinichi Someya ${ }^{1}$ \\ ${ }^{1}$ Department of Aging and Geriatric Research, University of Florida, Gainesville, Florida 32610, ${ }^{2}$ Center for Hearing and Deafness, State University of \\ New York at Buffalo, New York 14214, ${ }^{3}$ Whitney Laboratory, University of Florida, St Augustine, Florida 32080, and ${ }^{4}$ Department of Applied Biological \\ Chemistry, University of Tokyo, Yayoi, Tokyo 113, Japan
}

Glucose-6-phosphate dehydrogenase (G6PD) is the first and rate-limiting enzyme of the pentose phosphate pathway; it catalyzes the conversion of glucose-6-phosphate to 6-phosphogluconate and NADP ${ }^{+}$to NADPH and is thought to be the principal source of NADPH for the cytosolic glutathione and thioredoxin antioxidant defense systems. We investigated the roles of G6PD in the cytosolic antioxidant defense in the cochlea of G6pd hypomorphic mice that were backcrossed onto normal-hearing CBA/CaJ mice. Young G6pd-deficient mice displayed a significant decrease in cytosolic G6PD protein levels and activities in the inner ears. However, G6pd deficiency did not affect the cytosolic NADPH redox state, or glutathione or thioredoxin antioxidant defense in the inner ears. No histological abnormalities or oxidative damage was observed in the cochlea of $G 6 p d$ hemizygous males or homozygous females. Furthermore, G6pd deficiency did not affect auditory brainstem response hearing thresholds, wave I amplitudes or wave I latencies in young males or females. In contrast, G6pd deficiency resulted in increased activities and protein levels of cytosolic isocitrate dehydrogenase 1, an enzyme that catalyzes the conversion of isocitrate to $\alpha$-ketoglutarate and NADP ${ }^{+}$to NADPH, in the inner ear. In a mouse inner ear cell line, knockdown of Idh1, but not G6pd, decreased cell growth rates, cytosolic NADPH levels, and thioredoxin reductase activities. Therefore, under normal physiological conditions, G6pd deficiency does not affect the cytosolic glutathione or thioredoxin antioxidant defense in mouse cochlea. Under G6pd deficiency conditions, isocitrate dehydrogenase 1 likely functions as the principal source of NADPH for cytosolic antioxidant defense in the cochlea.

Key words: antioxidant defense; cochlea; glutathione; NADPH; redox; thioredoxin

Significance Statement

Glucose-6-phosphate dehydrogenase (G6PD) is the first and rate-limiting enzyme of the pentose phosphate pathway; it catalyzes the conversion of glucose-6-phosphate to 6-phosphogluconate and NADP ${ }^{+}$to NADPH and is thought to be the principal source of NADPH for the cytosolic glutathione and thioredoxin antioxidant defense systems. In the current study, we show that, under normal physiological conditions, G6pd deficiency does not affect the cytosolic glutathione or thioredoxin antioxidant defense in the mouse cochlea. However, under G6pd deficiency conditions, isocitrate dehydrogenase 1 likely functions as the principal source of NADPH for cytosolic antioxidant defense in the cochlea.

\section{Introduction}

NADPH (reduced nicotinamide adenine dinucleotide phosphate) plays a crucial role in protecting cells from oxidative stress

\footnotetext{
Received Feb. 23, 2017; revised April 25, 2017; accepted April 26, 2017.

Author contributions:S.S. designed research; K.W., M.-J.K., D.D., C.H., H.-J.P., Z.M., and P.L. performed research; M.T. and R.S. contributed unpublished reagents/analytic tools; K.W., M.-J.K., D.D., C.H., H.-J.P., Z.M., M.T., P.L., and S.S. analyzed data; K.W., R.S., and S.S. wrote the paper.

This work was supported by McKnight Doctoral Fellowship to K.W., R03 DC011840, R01 DC012552, and R01 DC014437 to S.S., National Institutes of Health and National Institute on Deafness and Communication Disorders, American Federation for Aging Research Grant 12388 to S.S., University of Florida Claude D. Pepper Older Americans Independence Centers, National Institute of Health and National Institute on Aging Grant 1 P30 AG028740, and Japan Society for the Promotion of Science Grant-in-Aid for Scientific Research (A) Grant 26253081.

The authors declare no competing financial interests.

Correspondence should be addressed to Dr. Shinichi Someya, Department of Aging and Geriatric Research, University of Florida, 2004 Mowry Road, PO Box 112610, Gainesville, FL 32610. E-mail: someya@ufl.edu.
}

by serving as a cofactor for several antioxidant enzymes, including NADPH-dependent glutathione reductase (GSR) and thioredoxin reductase (TXNRD) (Evans and Halliwell, 1999; Stanton, 2012). NADPH also maintains the catalytic activity of catalase by binding to catalase to prevent the formation of inactive catalase (Kirkman and Gaetani, 2007). There are two major mechanisms by which NADPH can be formed (Ying, 2008). In the mitochondria, NADPH is generated from NADH and $\mathrm{NADP}^{+}$by mitochondrial transhydrogenase. NADPH is also generated from $\mathrm{NADP}^{+}$by isocitrate dehydrogenases 2 (IDH2), malic enzyme 3 (ME3), or glutamate dehydrogenase (GLUD1). In the cytosol, 
NADPH is generated from NADP ${ }^{+}$by glucose-6-phosphate dehydrogenase (G6PD), 6-phosphogluconate dehydrogenase (6PGD), isocitrate dehydrogenase 1 (IDH1), or malic enzyme 1 (ME1). Of these cytosolic NADPH-producing enzymes, G6PD is thought to be the principal source of NADPH for cytosolic antioxidant defenses (Stanton, 2012).

G6PD is the first and rate-limiting enzyme of the pentose phosphate pathway, catalyzing the conversion of glucose-6phosphate to 6-phosphogluconate and $\mathrm{NADP}^{+}$to NADPH (Ying, 2008; Stanton, 2012). G6PD is an X-linked gene that consists of 13 exons and spans $18 \mathrm{~kb}$ (Nkhoma et al., 2009). G6PD is regulated by the cytosolic NADPH/NADP ${ }^{+}$ratio and activated in response to oxidative stress. G6PD deficiency was first discovered during the testing of the antimalarial medication primaquine (Riganti et al., 2012) and is the most prevalent enzymatic disorder of red blood cells (RBCs) due to increased susceptibility of erythrocytes to oxidative stress (Beutler, 1994). More than 400 million individuals worldwide are affected by this condition. Although most G6PD-deficient individuals are asymptomatic, factors that exert excessive oxidative stress, including antimalarial medication and viral infections, can cause acute hemolytic anemia in individuals with G6PD deficiency (Beutler, 1994; Cappellini and Fiorelli, 2008; Minucci et al., 2009; Riganti et al., 2012). Moreover, G6PD deficiency accelerates cellular senescence and increases oxidative stress markers in human fibroblasts (Ho et al., 2000). In adult cardiomyocytes, G6PD activity is increased following exposure to hydrogen peroxide, whereas inhibition of G6PD decreases cytosolic reduced glutathione (GSH) levels and results in cardiomyocyte contractile dysfunction (Jain et al., 2003). In G6pd hypomorphic mice, cardiac relaxation and contractile performance were impaired following ischemia-reperfusion (Jain et al., 2004). This was associated with depletion of total glutathione. G6pd hypomorphic mice also display increased levels of oxidative damage markers and decreased levels of NADPH and GSH in the kidney (Xu et al., 2010). Together, those and numerous other reports indicate that G6PD plays critical roles in protecting the RBCs, heart, and kidney from ROS in humans and laboratory animals.

In the cochlea, the major sensory organ of hearing, the NADPH-dependent antioxidant defense systems also play critical roles in protecting cells from ROS. Following noise exposure, the activities of GSR and glutamate-cysteine ligase were elevated in the organ of Corti and stria vascularis (SV) of the cochlea of chinchillas (Jacono et al., 1998), whereas mice lacking glutathione peroxidase 1 (Gpx1) displayed more sensory hair cell loss and greater auditory brainstem response (ABR) threshold elevation following noise exposure (Ohlemiller et al., 2000). Overexpression of mitochondrial catalase reduced oxidative DNA damage in the cochlea and slowed age-related hearing loss in C57BL/6 mice (Someya et al., 2009). In patients suffering from Meniere's disease whose symptoms include fluctuating hearing loss, a significant decrease in the blood reduced glutathione (GSH)/oxidized glutathione (GSSG) ratios was observed (Calabrese et al., 2010). Importantly, an infant with neonatal hyperbilirubinemia from hemolysis due to G6PD deficiency and naphthalene exposure developed profound bilateral sensorineural hearing loss (Worley et al., 1996). Together, these reports support the idea that G6PD is likely the principal source of NADPH for the cytosolic antioxidant defense in the cochlea. In the current study, we tested the hypothesis that young G6pd hypomorphic mice on a normalhearing $\mathrm{CBA} / \mathrm{CaJ}$ background would show a decreased NADPH redox state, decreased glutathione and thioredoxin antioxidant defenses, and increased oxidative damage in the cytosol of the cochlea.

\section{Materials and Methods}

Animals

Male and female G6pd hypomorphic mice were obtained from the European Mouse Mutant Archive (RRID: IMSR_EM:00073). These G6pd hypomorphic mice were characterized previously (Sanders et al., 1997; Xu et al., 2010). CBA/CaJ mice were obtained from The Jackson Laboratory (RRID: IMSR_JAX:000654) (https://www.jax.org/strain/000654). All animal studies were conducted at the Association for Assessment and Accreditation of Laboratory Animal Care-approved University of Florida Animal Facility. Experiments were performed in accordance with protocols approved by the University of Florida Institutional Animal Care and Use Committee. Both male and female wild-type (WT) and G6pd-deficient mice littermates were used in the current study.

\section{Genotyping and DNA sequencing}

G6pd genotyping. G6pd $d^{-1 y}$ hemizygous males were mated with G6pd $d^{+1-}$ heterozygous females, and their offspring were genotyped with DNA extracted from a tail clip obtained at weaning. The following primers were used for genotyping: G6PD-forward, 5'-GGAAACTGGCTGTGC GCTAC-3'; and G6PD-reverse, 5' -TCAGCTCCGGCTCTCTTCTG-3'. The PCR cycling parameters were as follows (Nicol et al., 2000): $94^{\circ} \mathrm{C}$ for $2 \mathrm{~min}, 20 \mathrm{~s}$ at $94^{\circ} \mathrm{C}, 20 \mathrm{~s}$ at $58^{\circ} \mathrm{C}$, and $30 \mathrm{~s}$ at $72^{\circ} \mathrm{C}$ for 35 cycles with an extension for $5 \mathrm{~min}$ at $72^{\circ} \mathrm{C}$. PCR products were incubated with DdeI enzyme at $37^{\circ} \mathrm{C}$ for $1 \mathrm{~h}$ and then separated on $1.5 \%$ agarose gel. The expected band size for the WT and mutant allele was $214 \mathrm{bp}$ (cleaved) and 269 bp (uncleaved) (see Fig. 1a).

Cdh23 genotyping. Male and female G6pd-deficient mice were backcrossed for four generations onto the $\mathrm{CBA} / \mathrm{CaJ}$ mouse strain that does not carry the recessive AHL-susceptibility allele $\left(C d h 23^{753 \mathrm{~A}}\right)$. To confirm that G6pd $d^{+/ y}$ and G6pd $d^{-/ y}$ males and G6pd $d^{+/+}, G 6 p d^{+/-}$, and G6pd $d^{-1-}$ females have the same $C d h 23^{753 \mathrm{G} / 753 \mathrm{G}}$ genotype for $C d h 23$, we isolated DNA from these animals, amplified by PCR, and then sequenced the region of DNA containing the 753rd nucleotide in the $C d h 23$ gene $(N=$ 3 each of $G 6 p d^{+/ y}, G 6 p d^{-1 y}, G 6 p d^{+1+}, G 6 p d^{+1-}$, and G6pd $d^{-1-}$ mice) (see Fig. 1b). The following primers were used for the PCR: Cdh23forward, 5'-GATCAAGACAAGACCAGACCTCTGTC-3'; and Cdh23reverse, 5'-GAGCTACCAGGAACAGCTTGGGCCTG-3'. The size of the amplified PCR product was 360 bp (see Fig. 1b).

\section{$A B R$ hearing test}

At 3-5 months of age, ABRs were measured with a tone burst stimulus at $4,8,16,32,48$, and $64 \mathrm{kHz}$ using the TDT neurophysiology workstation (Tucker-Davis Technologies) in a sound isolation booth as previously described (Han et al., 2016). Mice were anesthetized with a mixture of xylazine hydrochloride ( $10 \mathrm{mg} / \mathrm{kg}$, i.m.) (Phoenix Urology of St. Joseph) and ketamine hydrochloride (40 mg/kg, i.m.) (Phoenix Urology of St. Joseph) by intraperitoneal injection and placed on a warm heating pad. Needle electrodes were placed subcutaneously at the vertex (noninverting or active), ipsilateral ear (reference), and contralateral ear (ground). At each frequency, the sound level was decreased in $10 \mathrm{~dB}$ steps from 90 to $10 \mathrm{~dB}$ SPL. A hearing threshold was defined as the lowest level that produced a noticeable $A B R$ response. ABR amplitudes and latencies for wave I were also measured at 8,16 , and $32 \mathrm{kHz}$ at $90 \mathrm{~dB}$ SPL for all animals. A wave I amplitude was determined by measuring the voltage difference between the highest positive value (peak) and greatest negative value (trough) for the first ABR wave as previously described by Chen et al. (2014). A wave I latency was measured as the amount of time elapsed from the onset of the stimulus to the peak of the first wave. We used 10-14 mice per group for ABR threshold, amplitude, and latency assessments. Following the ABR hearing measurements, tissues from the same mice were used to conduct histopathological analyses.

\section{Cochlear histology}

Spiral ganglion neuron (SGN) and SV evaluation. Following the ABR hearing measurements, the animals were killed by cervical dislocation, and the temporal bone was excised from the head and divided into cochlear and vestibular parts (Someya et al., 2010). The cochlea was then excised, immersed in a fixative containing 4\% PFA (Sigma-Aldrich) in PBS solution for $1 \mathrm{~d}$. Afterward, the cochleae were decalcified in $10 \%$ 
a

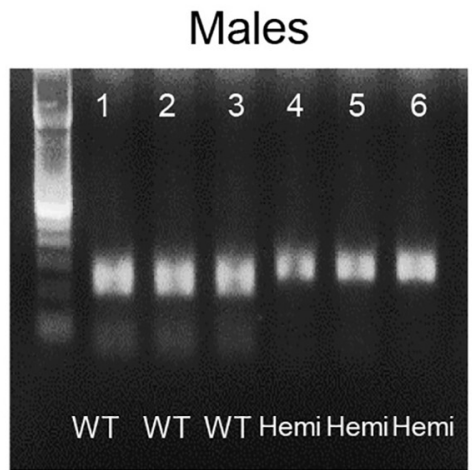

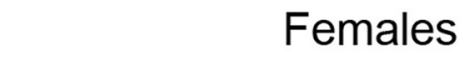

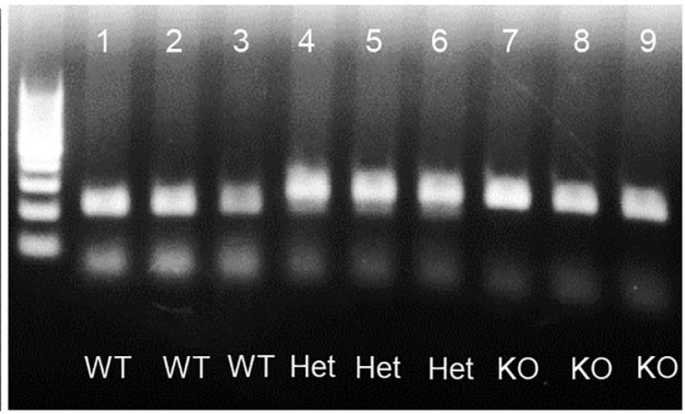

MT: 269 bps WT: 214 bps

b
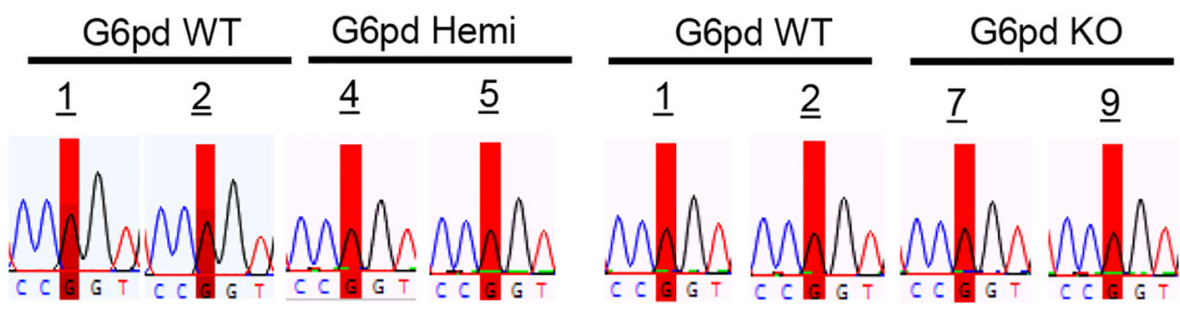

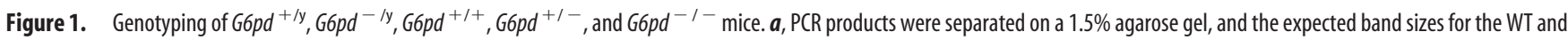
mutant alleles were 214 and 269 bp. $\boldsymbol{b}$, The C $d h 23$ gene in G6pd-deficient mice ( $N=3$ each) was sequenced. All the mice examined had the $C d h 23{ }^{753 G / 753 G}$ genotype. Red blocks represent the Cdh23 $3^{753 G}$ allele.

EDTA for 1 week, and embedded in paraffin. The paraffin-embedded specimens were sliced along the mid-modiolar axis into $5 \mu \mathrm{m}$ sections, mounted on silane-coated slides, stained with H\&E, and observed under a light microscope (Leica). Rosenthal's canal was divided into three regions (apical, middle, and basal), and the three regions were used for evaluation of cochlear histology. We used 3 or 4 mice per group for histopathological assessment. In each mouse, we evaluated every third modiolar section obtained from one cochlea for a total of 10 sections. Tissues from the same animals were used for cochleograms, SGN counting, and SV thickness measurement.

Cochleogram. For assessment of hair cell loss, the cochlea was excised, immersed in a fixative containing 4\% PFA (Sigma-Aldrich) in PBS solution for $1 \mathrm{~d}$. The number of inner hair cells (IHCs), first-row outer hair cells $(\mathrm{OHC} 1)$, second-row outer hair cells (OHC2), and third-row outer hair cells (OHC3) were counted over $0.24 \mathrm{~mm}$ intervals along the entire length of the cochlea under the microscope at $400 \times$ magnification as previously described (Ding et al., 1999, 2013). The counting results were then entered into a custom computer program designed to compute a cochleogram that shows the number of missing IHC and OHC1-3 as a function of percentage distance from the apex of the cochlea. Frequencyplace map for mouse cochlea was shown on the abscissa in the figures as previously described (Müller et al., 2005; Ding et al., 2016).

SGN counting. SGNs were counted in the apical, middle, and basal regions of the cochlear sections using a $40 \times$ objective as previously described (Someya et al., 2010). Type I and Type II neurons were not differentiated, and cells were identified by the presence of a nucleus. The corresponding area of the Rosenthal canal was measured in digital photomicrographs of each canal profile. The perimeter of the canal was traced with a cursor using ImageJ software (National Institutes of Health, RRID: SCR_003070). The computer then calculated the area within the outline. SGN survival was calculated as the number of SGNs $/ \mathrm{mm}^{2}$. Six to nine sections of the apical, middle, and basal turns were evaluated in one cochlea per mouse. We used 4 or 5 mice per group for SGN counting.

SV thickness measurements. SV thickness was measured in $40 \times$ images of H\&E-stained mouse cochlear tissues. In the ImageJ software (National Institutes of Health, RRID: SCR_003070), the measurement was made by using a cursor to draw a line from the margin of the stria to the junction of the basal cells within the spiral ligament halfway between the attachment of Reissner's membrane and the spiral prominence (Han et al., 2016). Measurements were made at the basal, middle, and apical regions of the cochlea for each mouse, and averages of each region were calcu-
Table 1. Fertility of G6pd-deficient mice ${ }^{a}$

\begin{tabular}{lcclll}
\hline Sex & WT & Hemi & Hetero & Homo & Total \\
\hline Male & & & & & \\
Expected & 69 & 69 & 0 & 0 & 138 \\
$\quad$ Observed & 70 & 68 & 0 & 0 & 138 \\
Female & & & & & \\
$\quad$ Expected & 32 & 0 & 65 & 32 & 129 \\
$\quad$ Observed & 24 & 0 & 76 & 29 & 129 \\
\hline
\end{tabular}

${ }^{a}$ The expected numbers are based on the predicted Mendelian inheritance. The observed indicates the genotypes obtained from the wild-type or hemizygous male mice crossed with heterozygous female mice.

lated for each mouse. Six to nine sections of the apical, middle, and basal turns were evaluated in one cochlea per mouse. We used 4 or 5 mice per group for SV thickness measurements.

\section{Immunohistochemistry}

For confocal-based immunohistochemistry, cochlear sections were rehydrated before the antigen retrieval process $(0.01 \mathrm{~m}$ sodium citrate, $\mathrm{pH} 6.0$, for $30 \mathrm{~min}$ at $60^{\circ} \mathrm{C}$ ). Sections were then incubated in diluted primary antibody (G6pd rabbit polyclonal, Bethyl Laboratories, RRID: AB_2247325) overnight at $4^{\circ} \mathrm{C}$. The following day, the slides were washed extensively, and appropriate fluorescently labeled secondary antibodies (Jackson ImmunoResearch Laboratories) were applied for $2 \mathrm{~h}$ at $37^{\circ} \mathrm{C}$. Coverslips were mounted with $60 \%$ glycerol in TBS containing p-phenylenediamine (to inhibit fluorescence quench). Preparations were viewed and digital images gathered with a Leica SP5 laser scanning confocal microscope. Figures were assembled using CorelDRAW 12 software (RRID: SCR_014235).

\section{Isolation of cytosol}

Labyrinth tissues, including bony shell, cochlear lateral wall, cochlear basilar membrane, cochlear modiolus, utricle, saccule, and three semicircular canals, were homogenized using a tissue grinder (Wheaton Dounce Tissue Grinder, Fisher Scientific) containing $1 \mathrm{ml}$ of Tris buffer (10 mm Tris, 1 mm EDTA, $320 \mathrm{~mm}$ sucrose, $\mathrm{pH}$ 7.4) on ice and then centrifuged at $720 \times g$ for $5 \mathrm{~min}$ at $4^{\circ} \mathrm{C}$ to get a nuclear fraction (pellet). The supernatant was centrifuged at $12,000 \times g$ for $10 \mathrm{~min}$ at $4^{\circ} \mathrm{C}$ to get a cytosolic fraction (supernatant). 

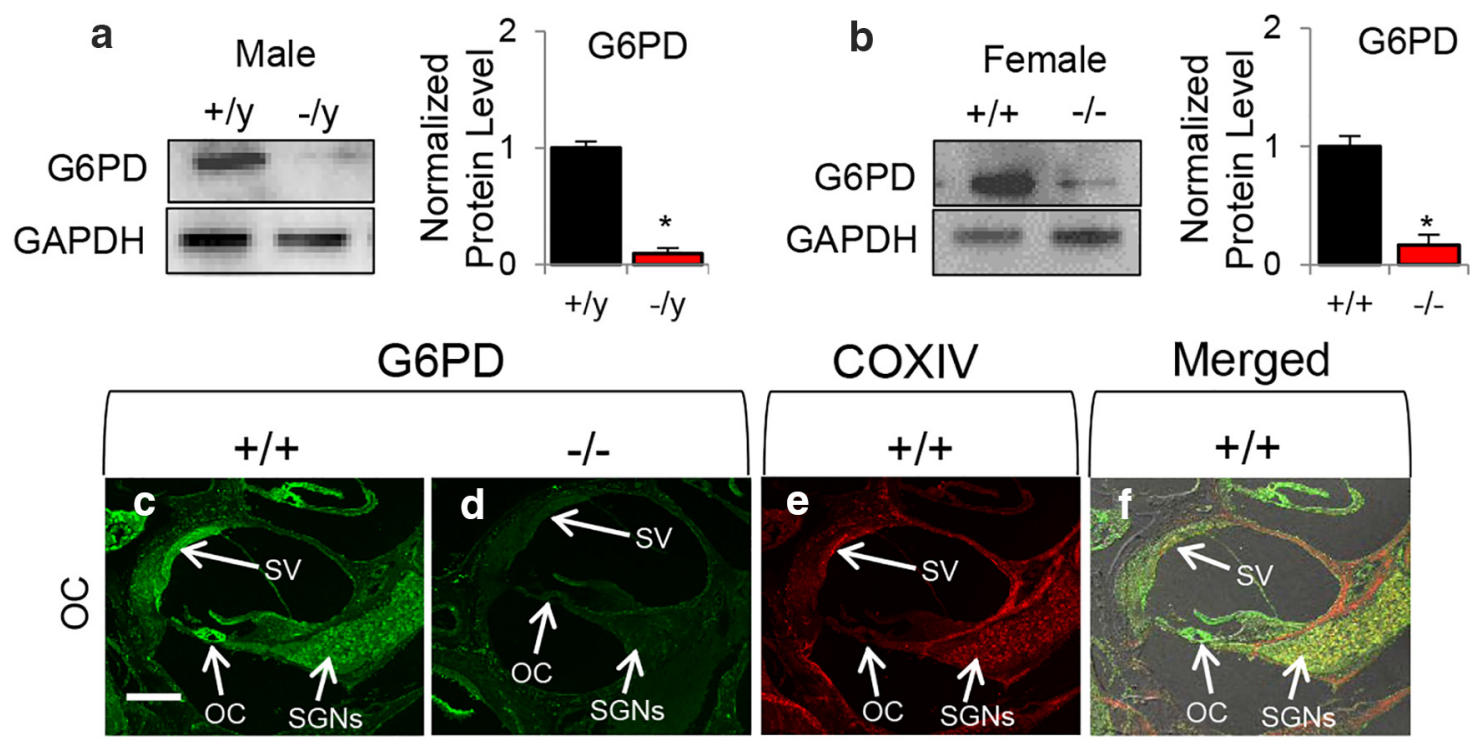

G6PD
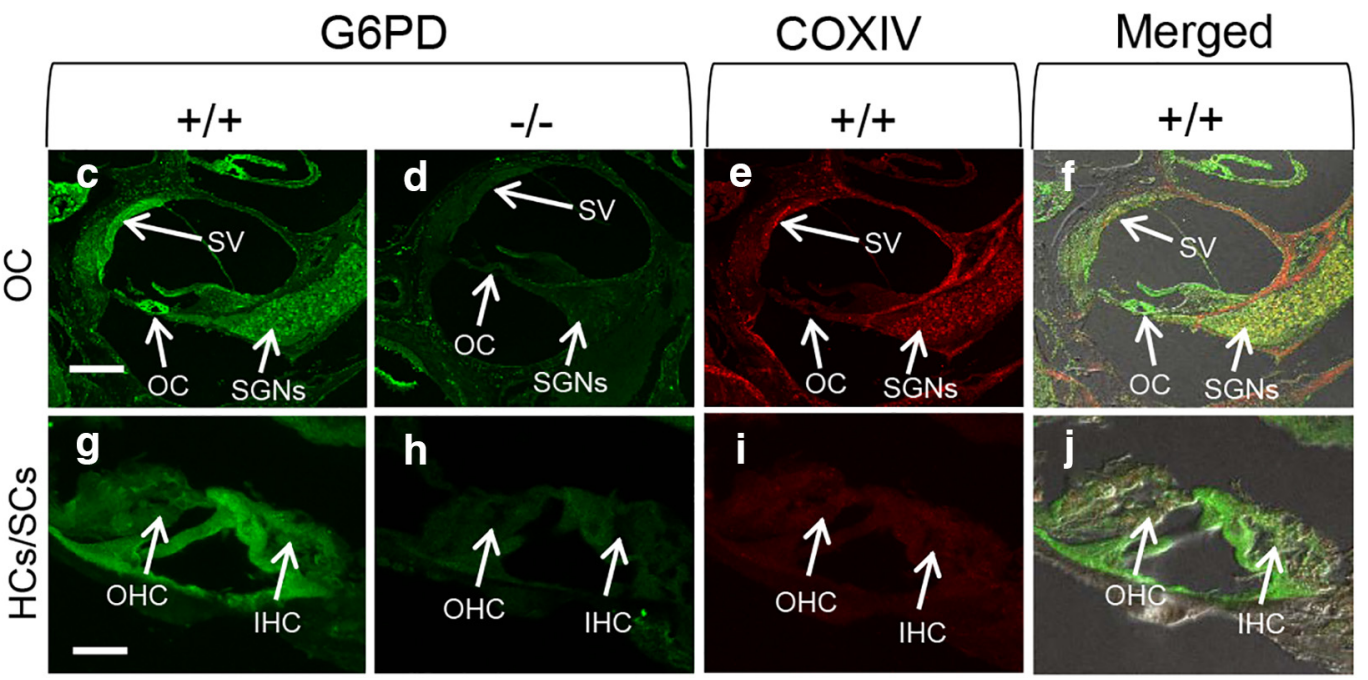

Figure 2. Localization of G6PD protein in the cochlea. $\boldsymbol{a}, \boldsymbol{b}$, Western blotting analysis of G6PD protein levels in the inner ear tissues from young G6pd ${ }^{+/ y}$ and G6pd $^{-/ y}$ males $(\boldsymbol{a})$ and G6pd $^{+/+}$ and G6pd ${ }^{-1-}$ females (b). GAPDH was used as a cytosolic marker. Data are mean \pm SEM $(N=4) .{ }^{*} p<0.05 . \boldsymbol{c}-\boldsymbol{j}$, G6PD staining (green; $\left.\boldsymbol{c}, \boldsymbol{d}, \boldsymbol{g}, \boldsymbol{h}\right)$, COXIV staining (mitochondrial marker; red; $\boldsymbol{e}$, $\boldsymbol{i})$, and merged staining $(\boldsymbol{f}, \boldsymbol{j})$ were detected in the organ of Corti regions $(\boldsymbol{c}, \boldsymbol{e}, \boldsymbol{f}), \mathrm{OHC}$, IHC, and supporting cells $(\boldsymbol{g}, \boldsymbol{i}, \boldsymbol{j})$, SGNs $(\boldsymbol{c})$, or SV (c) from 3-month-old WT $(\boldsymbol{c}, \boldsymbol{e}, \boldsymbol{f}, \boldsymbol{g}, \boldsymbol{i}, \boldsymbol{j})$ and G6pd ${ }^{-1-}(\boldsymbol{d}$, h) females. Arrows indicate hair cells and supporting cells in the organ of Corti region. Scale bars: $\boldsymbol{c}, 140 \mu \mathrm{m} ; \boldsymbol{g}, 17 \mu \mathrm{m}$.

\section{Western blotting}

Twenty micrograms of total protein was fractionated by $10 \%$ of SDSPAGE and transferred to nitrocellulose membranes (Bio-Rad). Membranes were incubated with the primary antibody followed by the HRP-linked secondary antibody. A chemiluminescent detection reagent (ECL Prime, GE Healthcare Life Sciences) was used to visualize proteins. The band intensity was quantified using the ImageJ software (National Institutes of Health, RRID: SCR_003070), and the levels of each protein were normalized by loading controls. Primary antibodies used were as follows: G6pd (rabbit polyclonal, used at 1:1000 dilution, Bethyl Laboratories, RRID: AB_2247325), Pgd (rabbit monoclonal, used at 1:1000 dilution, Abcam, RRID: AB_11144133), Idh1 (rabbit polyclonal, used at 1:1000 dilution, Proteintech, RRID:AB_2123159), Me1 (rabbit polyclonal antibody, used at 1:1000 dilution, Santa Cruz Biotechnology, RRID:AB_10838790), Txn1 (rabbit polyclonal antibody, used at 1:500 dilution, Abcam, RRID: AB_778412), Txnrd1 (rabbit polyclonal antibody, used at 1:500 dilution, Abcam, RRID: AB_2210118), and GAPDH (rabbit polyclonal, used at 1:50,000 dilution, Abcam, RRID: AB_2107448). Secondary antibodies used were as follows: rabbit (1:5000 dilution, GE Healthcare Life Sciences, RRID: AB_772206).

\section{Measurement of oxidative damage markers}

Oxidative DNA damage marker. DNA was extracted using the DNeasy Blood and Tissue Kit (QIAGEN) according to the manufacturer's instructions. DNA concentration was measured using the NanoDrop ND-100 Spectrophotometer. The level of the oxidative DNA damage marker 8-oxoguanine (8-OHdG) was analyzed using the Oxyselect Oxidative DNA Damage ELISA kit (Cell Biolabs) according to the manufacturer's instructions. In brief, the 96 well plate was coated with 8-OHdG conjugate $(1 \mu \mathrm{g} / \mathrm{ml})$, and DNA extracted from inner ears was converted to single-stranded DNA at $95^{\circ} \mathrm{C}$ for $5 \mathrm{~min}$ and was cooled down on ice. DNA samples were digested to nucleosides by incubating with 5-20 units of nuclease P1 (Sigma-Aldrich) for $2 \mathrm{~h}$ at $37^{\circ} \mathrm{C}$ in a final concentration of $20 \mathrm{~mm}$ sodium acetate, $\mathrm{pH}$ 5.2, followed by treatment with 5-10 units of alkaline phosphatase (Sigma-Aldrich) for $1 \mathrm{~h}$ at $37^{\circ} \mathrm{C}$ in a final concentration of $100 \mathrm{~mm}$ Tris, $\mathrm{pH}$ 7.5. The reaction mixture was centrifuged for $5 \mathrm{~min}$ at $6000 \times \mathrm{g}$, and the supernatant was used for the 8-OHdG ELISA assay. Fifty microliters of samples or $8-\mathrm{OHdG}$ standards was added to the wells of the 8-OHdG conjugate-coated plate and incubated for $10 \mathrm{~min}$ at room temperature on an orbital shaker. Fifty microliters of the diluted anti8-OHdG antibody was added to each well and incubated for $1 \mathrm{~h}$ at room temperature on an orbital shaker. After washing with $1 \times$ washing buffer three times, $100 \mu$ l of the diluted secondary antibody-enzyme conjugate was added to all wells and incubated at room temperature for $1 \mathrm{~h}$ on an orbital shaker. After washing with $1 \times$ washing buffer three times, $100 \mu$ l of substrate solution was added to each well and incubated for $10 \mathrm{~min}$ at room temperature. The reaction was stopped by adding $100 \mu \mathrm{l}$ of stop solution into each well. The absorbance was read at $450 \mathrm{~nm}$ in a spectrometer (Bio-Tek).

Oxidative protein damage marker. The level of oxidative protein damage marker, protein carbonyl, was analyzed in the cytosol of the cochlea using the Oxyblot Protein Oxidation Detection kit (EMD Millipore) according to the manufacturer's instructions. In brief, $8 \mu \mathrm{g}$ of cytosolic fractions was denatured by adding the same volume of $12 \%$ SDS for a final concentration of $6 \%$ SDS and was derivatized by adding 2 volumes of $1 \times$ DNPH solution to the tubes and incubated at room temperature for $15 \mathrm{~min}$. One and a half volumes of neutralization solution was added to tubes to stop the reaction. 2-Mercaptoethanol (1-1.5 $\mu \mathrm{l} ; 5 \% \mathrm{v} / \mathrm{v})$ was added to the tubes to achieve a final concentration of $0.74 \mathrm{M}$ solution to reduce the samples. Samples were loaded into a polyacrylamide gel ( $4 \%-$ $20 \%$ ) (Bio-Rad) and separated at $100 \mathrm{~V}$ for $90 \mathrm{~min}$. Proteins on the gel were transferred to a nitrocellulose membrane (Bio-Rad). The membrane was incubated with the blocking buffer ( $4 \%$ skim milk in PBS) for $1 \mathrm{~h}$. The membrane was incubated with the primary antibody (1:150, diluted in the blocking buffer) overnight at $4^{\circ} \mathrm{C}$. The membrane was washed with PBS-T containing $0.05 \%$ (v/v) Tween 20 (Sigma-Aldrich) in PBS for 10 min three times. The membrane was incubated with the secondary antibody (1:300, diluted in the blocking buffer) for $1 \mathrm{~h}$ at room 
temperature. The membrane was washed with PBS-T for $10 \mathrm{~min}$ three times. The membrane was developed with ECL Prime (GE Healthcare). The intensity of bands was quantified using ImageJ software (National Institutes of Health, RRID: SCR_003070).

Measurement of antioxidant activities GSR activity. The activity of GSR was measured using the Glutathione Reductase Assay kit (Sigma-Aldrich) according to the manufacturer's instructions. In brief, $20 \mu \mathrm{l}$ of cytosolic fractions was added to a well in the 96 well plate and then $180 \mu \mathrm{l}$ of mixture containing $50 \mu \mathrm{l}$ of $1 \mathrm{~mm}$ GSSG, $20 \mu \mathrm{l}$ of assay buffer, $50 \mu \mathrm{l}$ of 0.75 mM DTNB, and $60 \mu \mathrm{l}$ of $0.1 \mathrm{~mm}$ NADPH was added to the well. The absorbance was read at $405 \mathrm{~nm}$ every $10 \mathrm{~s}$ for $2 \mathrm{~min}$ in a spectrometer (Bio-Tek) to calculate the activity. All samples were run in duplicate.

Thioredoxin reductase activity. The activity of thioredoxin reductase was measured using the Thioredoxin Reductase Assay kit (SigmaAldrich) according to the manufacturer's instructions. In brief, $10 \mu \mathrm{l}$ of cytosolic fractions was added to wells in the 96 well plate and then $190 \mu \mathrm{l}$ of mixture containing $180 \mu \mathrm{l}$ of working buffer (100 mM potassium phosphate, $10 \mathrm{~mm}$ EDTA, and $0.24 \mathrm{~mm}$ NADPH), $6 \mu \mathrm{l}$ of $100 \mathrm{~mm}$ DTNB, and $4 \mu \mathrm{l}$ of either $1 \times$ assay buffer (100 mm potassium phosphate, $\mathrm{pH}$ 7.0, $10 \mathrm{~mm}$ EDTA) or thioredoxin reductase inhibitor was added to the wells. The absorbance was read at $412 \mathrm{~nm}$ every $10 \mathrm{~s}$ for $2 \mathrm{~min}$ in a spectrometer (Bio-Tek) to calculate the activity. All samples were run in duplicate.

Catalase activity. The activity of catalase was measured using the Catalase Assay kit (SigmaAldrich) according to the manufacturer's instructions. In brief, $25 \mu \mathrm{l}$ of cytosolic fractions (5-10 $\mu \mathrm{g}$ protein/ $\mu \mathrm{l}$ ) was mixed with $50 \mu \mathrm{l}$ of $1 \times$ assay buffer and $25 \mu \mathrm{l}$ of $200 \mathrm{~mm} \mathrm{H}_{2} \mathrm{O}_{2}$ solution and incubated for $2 \mathrm{~min}$ at room temperature. The reaction was stopped by adding a stop solution (15 mm sodium azide in water). Then, $10 \mu \mathrm{l}$ of the $100 \mu \mathrm{l}$ reaction mixture was mixed with $990 \mu \mathrm{l}$ of the color reagent $(150 \mathrm{~mm}$ potassium phosphate buffer, $\mathrm{pH} 7.0$, containing $0.25 \mathrm{~mm} 4$-aminoantipyrine and $2 \mathrm{~mm} 3,5-$ dichloro-2-hydroxybenzensulfonic acid) in a new tube by inversion. After $15 \mathrm{~min}$ of incubation for color development, the absorbance was measured at $520 \mathrm{~nm}$ in a spectrometer (Bio-Tek). Activity ( $\mu \mathrm{M} / \mathrm{min} / \mathrm{mg}$ protein or $\mathrm{U} / \mathrm{mg}$ protein) was calculated using the following equation: $\Delta \mu \mathrm{M}\left(\mathrm{H}_{2} \mathrm{O}_{2}\right)=\mathrm{A} 520$ (Blank) - A520 (Sample). All samples were run in duplicate.

Superoxide dismutase (SOD) activity. SOD activity was measured using the SOD Activity Kit (Sigma-Aldrich) according to the manufacturer's instructions. Briefly, $20 \mu \mathrm{l}$ of the cytosolic fraction was added to each well of a 96 well plate followed by $200 \mu \mathrm{l}$ of the WST working solution. Twenty microliters of the enzyme working solution was added to each sample, and the 96 well plate was incubated at $37^{\circ} \mathrm{C}$ for $20 \mathrm{~min}$. The absorbance was read at $450 \mathrm{~nm}$ in a spectrophotometer. The SOD activity was calculated as the inhibition rate. All samples were run in duplicate.

\section{Measurement of NADPH}

NADPH levels were determined by the method of Zerez et al. (1987). Briefly, $200 \mu \mathrm{l}$ of the cytosolic fractions was mixed with $180 \mu \mathrm{l}$ of a

a
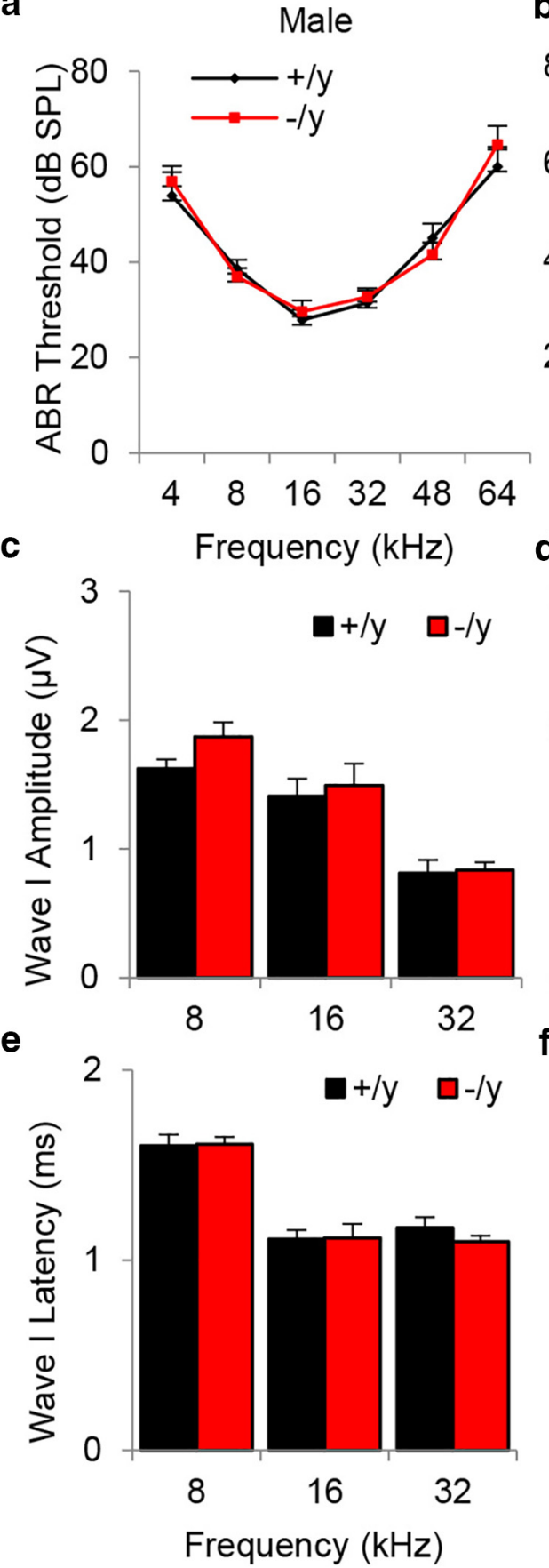

Figure 3. Assessment of ABR hearing thresholds, wave I amplitudes, and wave I latencies in young G6pd ${ }^{+/ y}$, G6pd $^{-/ y}$, $\mathrm{GGpd}^{+/+}, \mathrm{GGpd}^{+/-}$, and G6pd ${ }^{-1-}$ mice. $\boldsymbol{a}, \boldsymbol{b}, \mathrm{ABR}$ hearing thresholds were measured at 4, 8, 16, 32, 48, and 64 kHz in 3- to 5-month-old G6pd $d^{+/ y}$ and G6pd $d^{-/ y}$ males $(\boldsymbol{a})$ and G6pd $d^{+/+}, G_{6 p d^{+/-}}$, and G6pd $d^{-1-}$ females $(\boldsymbol{b})(N=10-14) . \boldsymbol{c}, \boldsymbol{d}, \mathrm{ABR}$ amplitudes of wave I were measured at $90 \mathrm{~dB}$ at 8, 16, and $32 \mathrm{kHz}$ from 3- to 5-month-old G6pd ${ }^{+/ \mathrm{y}}$ and G6pd ${ }^{-/ \mathrm{y}}$ males (c) and ${\mathrm{G} 6 p d^{+/+}}^{+1}$ and G6pd $d^{-1-}$ females (d).e, $\boldsymbol{f}, \mathrm{ABR}$ latencies of wave I were measured at $90 \mathrm{~dB}$ at 8, 16, and $32 \mathrm{kHz}$ from 3- to 5-month-old G6pd $d^{+/ y}$ and G6pd $d^{-/ y}$ males $(e)$ and G6pd $d^{+/+}$and G6pd $d^{-1-}$ females $(\boldsymbol{f})(N=10-14)$. Data are mean \pm SEM. b

20

0

$\begin{array}{llllll}4 & 8 & 16 & 32 & 48 & 64\end{array}$

Frequency $(\mathrm{kHz})$

3

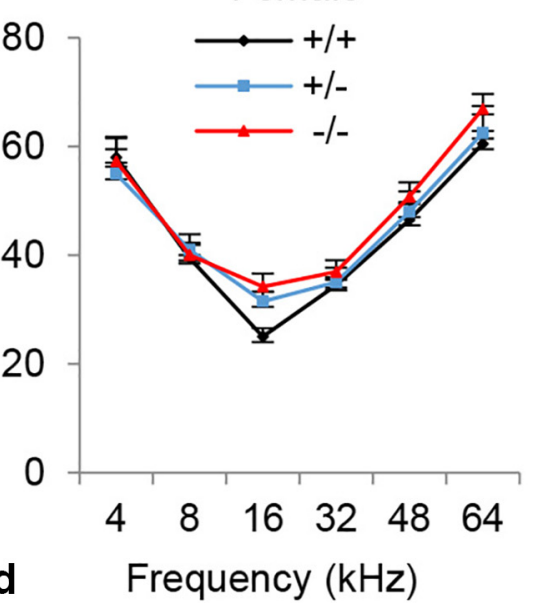

$\mathbf{a}+1+\square-1-$

2

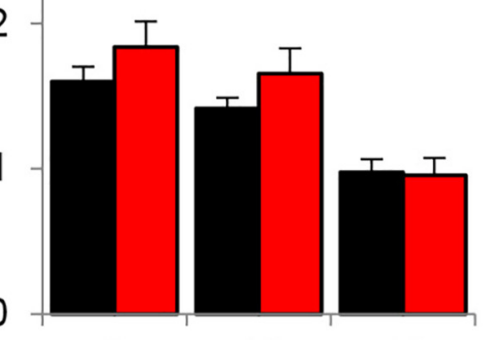

f

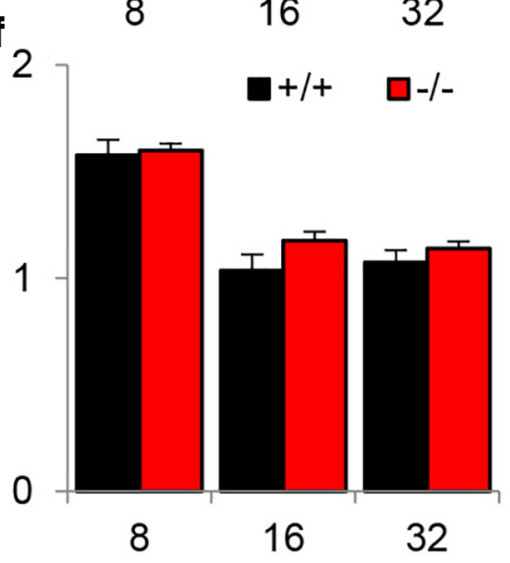

Frequency $(\mathrm{kHz})$

nicotinamide solution (10 mM nicotinamide, $20 \mathrm{~mm} \mathrm{NaHCO}_{3}$, and $100 \mathrm{mM} \mathrm{Na}_{2} \mathrm{CO}_{3}$ ) and underwent three freeze-thaw cycles. To destroy $\mathrm{NADP}^{+}$in the samples, $90 \mu \mathrm{l}$ of the mixture was incubated in a heating block for $30 \mathrm{~min}$ at $60^{\circ} \mathrm{C}$. Twenty-five microliters of each unheated and heated sample was mixed with $225 \mu \mathrm{l}$ of a reaction mixture (100 mM Tris, $5 \mathrm{~mm}$ EDTA, $0.5 \mu \mathrm{M}$ thiazolyl blue tetrazolium bromide, $2 \mu \mathrm{M}$ phenazine ethosulfate, and 1.3 U glucose-6-phosphate dehydrogenase, $\mathrm{pH}$ 8.0) and incubated for $5 \mathrm{~min}$ at $37^{\circ} \mathrm{C}$. The reaction mixture was then transferred to each well of a 96 well plate, and the reaction was initiated by adding 

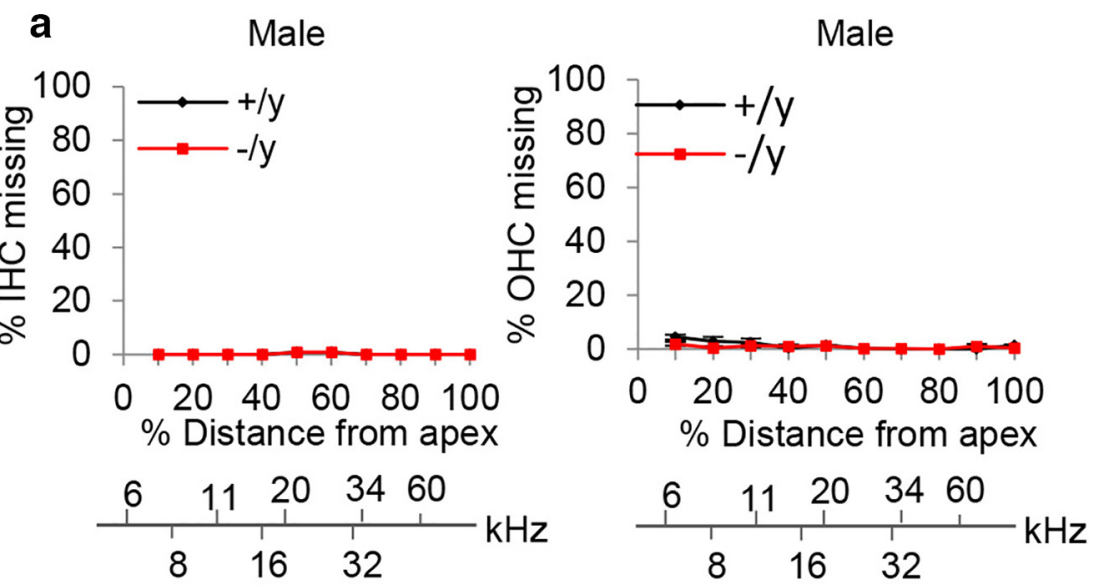

b
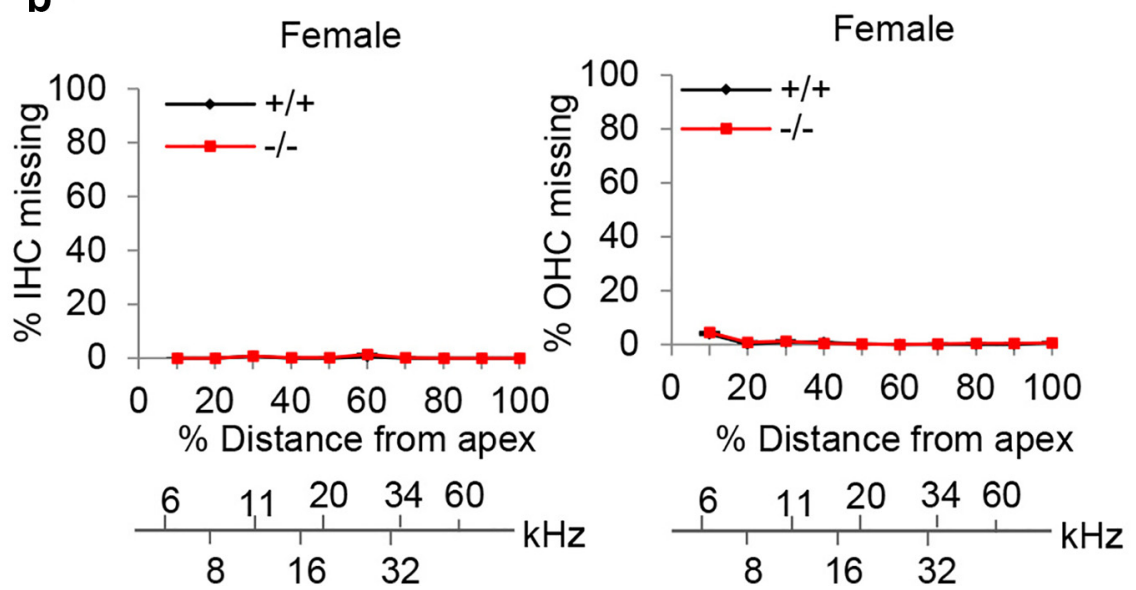

Figure 4. Cochleograms of young G6pd ${ }^{+/ y}, G 6 p d^{-1 y}, G 6 p d^{+/+}$and G6pd $d^{-1-}$ mice. $\boldsymbol{a}, \boldsymbol{b}$, Cochleograms were recorded and averaged in the cochlear tissues of 3- to 5-month-old G6pd ${ }^{+/ y}$, GGpd $^{-1 y}(\boldsymbol{a})(N=4)$ and $\mathrm{GGpd}^{+/+}$, and G6pd ${ }^{-1-}$ females (b) $(N=4)$. Graphs show percentage loss of IHCs (left panels) and OHCs (right panels) as function of percentage distance from the apex. Data are mean \pm SEM. Bottom, $x$-axis shows the frequency-place map for the mouse cochlea (Müller et al., 2005).

$1 \mathrm{~mm}$ of glucose-6-phosphate. The absorbance was read at $570 \mathrm{~nm}$ every $10 \mathrm{~s}$ for $3 \mathrm{~min}$ in a spectrophotometer (Bio-Tek). The reaction rates were calculated, and NADPH levels were determined as the ratio of NADPH (heated sample) to the total of $\mathrm{NADP}^{+}$and NADPH (unheated sample). All reagents used in this assay were purchased from Sigma-Aldrich. All samples were run in duplicate.

\section{Measurement of total GSH and GSSG}

Labyrinth tissues were homogenized using a tissue grinder (Wheaton Dounce Tissue Grinder, Fisher Scientific) containing $1 \mathrm{ml}$ of homogenization buffer (10 mu Tris, 20 mm EDTA, 320 mm sucrose, pH 7.4) on ice and then centrifuged at $12,000 \times g$ for $10 \mathrm{~min}$ at $4^{\circ} \mathrm{C}$. The supernatants are the cytosolic fractions. One hundred microliters of the cytosolic fraction was used for the measurements of cytosolic glutathione contents. Total glutathione (GSH + GSSG) and GSSG levels were determined by the method of Rahman et al. (2006). The rates of 5' -thio-2-nitrobenzoic acid (TNB) formation were calculated, and the total glutathione (tGSH) and GSSG concentrations in the samples were determined by using linear regression to calculate the values obtained from the standard curve. The GSH concentration was determined by subtracting the GSSG concentration from the tGSH concentration. All samples were run in duplicate. All reagents used in this assay were purchased from Sigma-Aldrich.

\section{Measurement of G6PD and 6PGD activities}

The activities of G6PD and 6PGD were measured as previously described (Shan et al., 2014). In brief, $20 \mu \mathrm{l}$ of the cytosolic fractions was added to $180 \mu \mathrm{l}$ of a buffer solution ( $50 \mathrm{~mm}$ Tris, $1 \mathrm{~mm} \mathrm{MgCl}, \mathrm{pH} 8.1$ ) in two separate tubes. In one tube, glucose6-phoshate $(0.2 \mathrm{~mm})$, 6-phosphogluconate $(0.2 \mathrm{~mm})$, and $\mathrm{NADP}^{+}(0.1 \mathrm{~mm})$ were added to obtain total (G6PD + 6PGD) activity. In a separate tube, only 6-phosphogluconate $(0.2$ $\mathrm{mm})$ and $\mathrm{NADP}^{+}(0.2 \mathrm{~mm})$ were added to measure 6PGD activity. Enzymatic activity was measured by the rate of increase in the absorbance at $340 \mathrm{~nm}$ in a microplate reader (Molecular Devices) from the conversion of $\mathrm{NADP}^{+}$to NADPH. Measurements were obtained every $20 \mathrm{~s}$ for $10 \mathrm{~min}$. G6PD activity was then calculated by subtracting 6PGD activity from total enzyme activity.

\section{Measurement of IDH1 activity}

The activities of IDH1 were measured by the Kornberg method (Kornberg, 1955). In brief, $20 \mu \mathrm{l}$ of the cytosolic fractions of each sample was added in each well of a 96 well plate, and then $180 \mu \mathrm{l}$ of a reaction mixture $(33 \mathrm{~mm}$ $\mathrm{KH}_{2} \mathrm{PO}_{4} \cdot \mathrm{K}_{2} \mathrm{HPO}_{4}, 3.3 \mathrm{~mm} \mathrm{MgCl}, 167 \mu \mathrm{M}$ $\mathrm{NADP}^{+}$, and $167 \mu \mathrm{M}(+)$-potassium Dsthreo-isocitrate monobasic) was added to each well. The absorbance was immediately read at $340 \mathrm{~nm}$ every $10 \mathrm{~s}$ for $10 \mathrm{~min}$ in a microplate reader (Molecular Devices). All samples were run in duplicate. The reaction rates were calculated, and the IDH1 activity in the sample was defined as the production of $1 \mu \mathrm{M}$ of NADPH per second.

\section{Measurement of ME1 activity}

The activities of ME1 were measured as previously described (Lee et al., 1980). Briefly, $20 \mu \mathrm{l}$ of each sample was added to a 96 well plate with $0.1 \mathrm{M}$ of Tris- $\mathrm{HCl}, 0.25 \mathrm{mg} / \mathrm{ml}$ of malic acid, and $0.34 \mathrm{~mm}$ of NADP $^{+}$at pH 8.0. The absorbance was observed as an increase at $340 \mathrm{~nm}$ in a microplate reader (Molecular Devices). The reaction rates were calculated, and ME1 activity was defined as the production of $1 \mu \mathrm{M}$ of NADPH per second.

\section{Cell line}

Mouse inner ear cell lines (HEI-OC1, RRID: CVCL_D899) were a gift from Dr. Federico Kalinec (Department of Head and Neck Surgery, University of California-Los Angeles). HEI-OC1 cells were maintained in high-glucose DMEM (Invitrogen) composed of heat-inactivated 10\% FBS (HyClone FBS, GE Healthcare Life Sciences) as described previously (Kalinec et al., 2003).

\section{Gene knockdown}

To generate siRNA-mediated knockdown cells, HEI-OC1 cells $\left(3 \times 10^{5}\right.$ cells per well) were plated on a 6 well plate the day before transfection. siRNA (Origene) targeted to mouse G6pd or IdhI and scrambled siRNA (control) were transfected with lipofectamine RNAi max (Invitrogen) according to the manufacturer's instructions. After $5 \mathrm{~d}$ of incubation, the expression of G6PD or IDH1 protein was examined by Western blotting.

\section{Cell growth rate}

After transfection, cells were incubated for $5 \mathrm{~d}$. The G6pd or Idh 1 knockdown cells were replated onto a 12 well plate. Cells were allowed to grow from 24 to $96 \mathrm{~h}$ in fresh medium. Cell growth rate was determined by the neutral red assay as previously described (Repetto et al., 2008). Briefly, cells were incubated in DMEM with $50 \mu \mathrm{g} / \mathrm{ml}$ of neutral red (SigmaAldrich) at $37^{\circ} \mathrm{C}$ for $2-3 \mathrm{~h}$. Cells were then treated with $200 \mu \mathrm{l}$ of neutral 
red solubilization solution ( $50 \%$ ethanol, $49 \%$ deionized water, and $1 \%$ glacial acetic acid; Sigma-Aldrich) per well. The 12 well plate was incubated at room temperature on a plate shaker overnight. The optical density values of the neutral red extract in each well were measured at $540 \mathrm{~nm}$ in a microplate reader spectrophotometer.

\section{Statistical analysis}

Two-way ANOVA with Bonferroni's post hoc tests (GraphPad Prism 4.03, RRID:SCR_002798) were used to analyze the ABR thresholds, wave I amplitude, and latency. One-way ANOVA with post-Tukey multiple-comparison test (GraphPad Prism 4.03) was used to analyze SGN densities, SV thickness, and cochleograms. Student's $t$ test was used to analyze the antioxidant enzyme activities, oxidative damage markers, GSH/GSSG, NADPH/totalNADP ${ }^{+}$, and Western blot analyses.

\section{Results}

Localization of G6PD in mouse cochlea To investigate the roles of G6PD in the cytosolic antioxidant defense in mouse cochlea, G6pd hypomorphic mice were backcrossed for four generations onto the CBA/CaJ mouse strain, a normal-hearing strain that does not carry the recessive early-onset hearing loss-susceptibility allele (Cdh23 ${ }^{753 \mathrm{~A}}$ ) (Zheng et al., 1999; Noben-Trauth et al., 2003). We genotyped $G 6 p d^{+/ y}$ and G6pd $d^{-/ y}$ males and $G 6 p d^{+/+}, G 6 p d^{+/-}$, and G6pd $d^{-1-}$ females by PCR genotyping (Fig. 1a) and then sequenced the Cdh23 gene in the DNA obtained from tails of young mice. We confirmed that all $G 6 p d^{+/ y}$ and $G 6 p d^{-/ y}$ males and G6pd $d^{+/+}, G_{6} p d^{+/-}$, and $G 6 p d^{-1-}$ females had the same WT genotype (Cdh23 $253 \mathrm{G} / 753 \mathrm{G})$ (Fig. 1b). G6pd-deficient mice on the CBA/CaJ background appeared phenotypically normal, are viable and fertile (Table 1), and no significant changes were observed in body weight between $G 6 p d^{+/ y}$ and $G 6 p d^{-/ y}$ males or between G6pd $d^{+/+}, G 6 p d^{+/-}$, and G6pd $d^{-1-}$ females (data not shown).

To confirm the genotyping results, we measured G6PD protein levels in the cytosol of the inner ear tissues from 3- to 5-month-old $G 6 p d^{+/ y}$ and G6pd $d^{-/ y}$ males and G6pd $d^{+/+}$, and G6pd $d^{-1-}$ females (Fig. $2 a, b$ ) by Western blotting. G6pd $d^{-1 y}$ hemizygous males displayed a 91\% decrease in G6PD protein levels (Fig. 2a), whereas $G 6 p d^{-1-}$ homozygous females displayed an $83 \%$ decrease in G6PD protein levels in the cytosol (Fig. $2 b$ ). These results were consistent with the previous report that G6pd hemizygous male mice show $\sim 15 \%$ of WT G6PD activity in the kidney (Xu et al., 2010). To investigate the subcellular localization of G6PD in the cochlea of young WT female mice, G6PD was immunostained with anti-G6PD antibody and observed by confocal microscopy. Figure $2 c-f$ shows an area of the cytological structures of the cochlear duct at low magnification: G6PD immunostaining was detected as a very strong signal in the cytosol of the IHC, OHCs, and some supporting cells of the organ of Corti, including inner and outer pillar cells (Fig. $2 c, g$ ). There was also a signal for G6PD
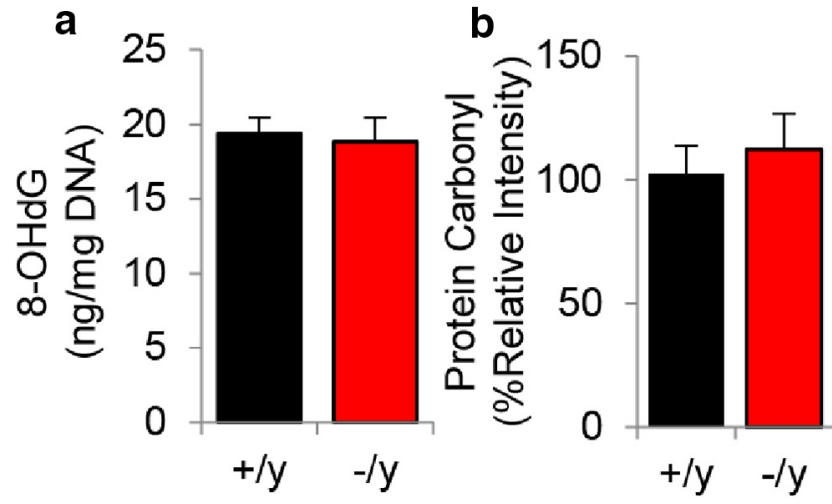

Figure 6. Assessment of oxidative DNA and protein damage in the inner ear tissues of young G6pd ${ }^{+/ y}$ and G6pd $d^{-/ y}$ mice. $\boldsymbol{a}, \boldsymbol{b}$, Levels of $8-0 \mathrm{HdG}$ as an oxidative DNA damage marker $(\boldsymbol{a})$ and protein carbonyl $(\boldsymbol{b})$ as an oxidative protein damage marker were measured in the inner ear tissues from 3- to 5-month-old G6pd ${ }^{+/ y}$ and G6pd ${ }^{-/ y}$ males $(N=4)$. Data are mean \pm SEM. 


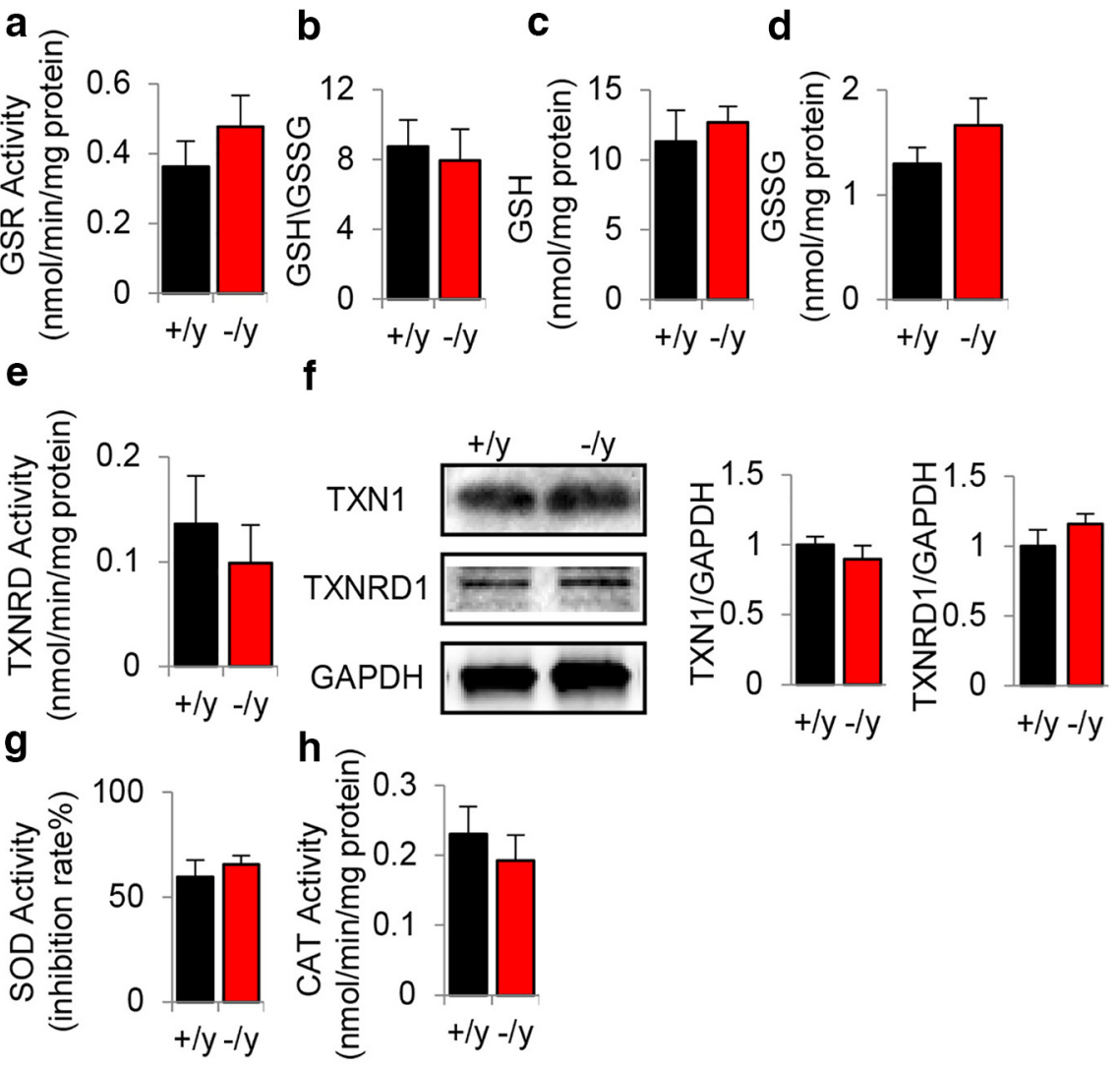

Figure 7. Assessment of glutathione and thioredoxin antioxidant defenses in the cytosol of the inner ear tissues from young $\mathrm{G}_{6 p d^{+/ y}}$ and G6pd ${ }^{-/ y}$ mice. $\boldsymbol{a}-\boldsymbol{i}$, The activities of GSR (a), the ratios of GSH/GSSG (b), the levels of GSH (c) and GSSG (d), the activities of TXNRD1 $(\boldsymbol{e})$, the levels of TXN1 and TXNRD1 $(\boldsymbol{f})$, and the activities of SOD $(\boldsymbol{g})$ and catalase $(\boldsymbol{h})$ were measured in the cytosol of the inner ear tissues from 3- to 5-month-old G6pd ${ }^{+/ y}$ and G6pd ${ }^{-/ y}$ mice $(N=4-6)$. Data are mean \pm SEM.

males or G6pd $d^{+/+}$and G6pd $d^{-1-}$ females (Fig. $4 a, b$ ). We also counted the numbers of SGNs in the apical, middle, and basal regions of the cochlea from young $G 6 p d^{+/ y}$ and $G 6 p d^{-/ y}$ males and $G 6 p d^{+/+}$and $G 6 p d^{-1-}$ females. There were no differences in the densities of SGNs between G6pd $d^{+/ y}$ and G6pd $d^{-/ y}$ males or between $G 6 p d^{+/+}$and G6pd $d^{-/-}$ females (Fig. $5 a-h$ ). To investigate whether G6pd deficiency results in SV degeneration in the cochlea, we measured the thickness of SV in the apical, middle, and basal regions of the cochlea from young G6pd $d^{+/ y}$ and $G 6 p d^{-/ y}$ males and $G 6 p d^{+/+}$and $G 6 p d^{-1-}$ females. In agreement with the hair cell and SGN counting results, there were no differences in the thickness of SV in the apical, middle, or basal regions of the cochlea between $G 6 p d^{+/ y}$ and $G 6 p d^{-/ y}$ males or between $\mathrm{GGpd}^{+/+}$and G6pd $d^{-1-}$ females (Fig. $5 i-p)$.

If $\mathrm{G} 6 \mathrm{PD}$ plays critical roles in protecting the cytosolic cellular components against ROS, then a defect in G6PD may result in early signs of oxidative damage in the cochlea. To test this hypothesis, we measured levels of the oxidative DNA damage marker 8 -OHdG in the cochlea from young $G 6 p d^{+/ y}$ and $G 6 p d^{-/ y}$ males. Because there were no sex differences in cochlear hair cell loss, SGN densities, or SV thickness between WT and G6pd-

immunostaining in SGN and SV (Fig. $2 c$ ). When comparing signal intensities for the G6PD immunolocalization between WT and $G 6 p d^{-1-}$ cochlear tissues from a young female, the SGNs from the G6pd $d^{-1-}$ mice clearly showed a lower level of G6PD than the WT (Fig. $2 c, d, g, h)$.

\section{G6pd deficiency does not affect hearing function in mice} If G6PD plays critical roles in the cytosolic antioxidant defense in the cochlea, then a defect in G6PD may result in increased oxidative damage in the cochlea and affect hearing function at a younger age. To test this hypothesis, we measured ABR thresholds, wave I amplitudes, and wave I latencies in G6pd $d^{+/ y}$ and $G 6 p d^{-/ y}$ males and G6pd $d^{+/+}$and G6pd $d^{-1-}$ females at 3-5 months of age. There were no differences in the ABR thresholds at $4,8,16,32,48$, or $64 \mathrm{kHz}$ between WT and G6pd-deficient males or females (Fig. $3 a, b$ ). In agreement with the ABR threshold results, there were no differences in wave I amplitudes or latencies at 8,16 , or $32 \mathrm{kHz}$ between WT and G6pd-deficient males or females (Fig. $3 c-f$ ). Together, these physiological analysis results show that G6pd deficiency does not affect hearing function in young mice that are on the $\mathrm{CBA} / \mathrm{CaJ}$ background.

\section{G6pd deficiency does not increase oxidative damage in mouse cochlea}

To investigate whether G6pd deficiency results in increased oxidative damage in cochlear hair cells, mean cochleograms were prepared from 3- to 5-month-old G6pd $d^{+/ y}$ and G6pd $d^{-/ y}$ males and $G 6 p d^{+/+}$and G6pd $d^{-1-}$ females. There were no differences in the numbers of IHCs or OHCs between $G 6 p d^{+/ y}$ and $G 6 p d^{-/ y}$ deficient mice, all the oxidative damage analyses were conducted in male mice. There were no differences in the levels of 8-OHdG in the cochlea between $G 6 p d^{+/ y}$ and G6pd $d^{-/ y}$ males (Fig. 6a). We also measured levels of protein carbonyl, a marker of oxidative protein damage, in the cytosol of the cochlea from young $G 6 p d^{+/ y}$ and G6pd $d^{-/ y}$ mice. There were no differences in the levels of protein carbonyl in the cochlea between $G 6 p d^{+/ y}$ and G6pd $d^{-/ y}$ mice (Fig. 6b). Together, these histological and biochemical analysis results show that G6pd deficiency does not increase oxidative damage in the HCs, SGNs, or SV in the cochlea of mice.

\section{G6pd deficiency does not affect the cytosolic glutathione or} thioredoxin antioxidant defense in the cochlea

GSR, a key member of the glutathione antioxidant defense system, requires NADPH for regeneration of GSH from GSSG (Kamerbeek et al., 2007; Deponte, 2013). To investigate whether G6pd deficiency affects the cytosolic glutathione antioxidant defense in the cochlea, we measured the activities of GSR and the levels of GSSG in the inner ear tissues from G6pd $d^{+/ y}$ and $G 6 p d^{-/ y}$ males at 3-5 months of age. Because there were no sex differences in cochlear hair cell loss, SGN densities, or SV thickness between WT and G6pd-deficient mice, all the biochemical analyses were conducted in male mice. There were no significant differences in the activities of GSR, the ratios of GSH/GSSG, or GSSG levels in the cytosol of the cochlea between G6pd $d^{+/ y}$ and $G 6 p d^{-/ y}$ mice (Fig. $7 a-d$ ). Thioredoxin reductase 1 (TXNRD1), a key member of the cytosolic thioredoxin antioxidant defense system, also requires NADPH for regeneration of reduced thioredoxin 
(red TXN) from oxidized thioredoxin ( ${ }_{\text {oxi }}$ TXN) (Evans and Halliwell, 1999). To investigate whether G6pd deficiency affects the cytosolic thioredoxin antioxidant defense in the cochlea, we measured the activities of cytosolic TXNRD1 and the protein levels of cytosolic TXN1 and TXNRD1 in the inner ear from young $G 6 p d^{+/ y}$ and G6pd $d^{-/ y}$ mice. There were no differences in the activities of TXNRD1 or the levels of TXN1 or TXNRD1 protein in the cytosol of the cochlea between $G 6 p d^{+/ y}$ and G6pd $d^{-/ y}$ mice (Fig. 7e,f). $\mathrm{NADPH}$ also maintains the catalytic activity of catalase by binding to catalase to prevent the formation of inactive catalase (Ying, 2008). We measured the activities of catalase that decomposes hydrogen peroxide into water (Evans and Halliwell, 1999) and SOD that decomposes superoxide into oxygen and hydrogen peroxide (Evans and Halliwell, 1999) in the cytosol of the inner ear tissues from $G 6 p d^{+/ y}$ and $G 6 p d^{-/ y}$ mice at 3-5 months of age. There were no differences in the activities of catalase or SOD in the cytosol of the cochlea between young G6pd $d^{+/ y}$ and $G_{6 p d} d^{-/ y}$ mice (Fig. 7g,h). Collectively, these results show that G6pd deficiency does not affect the cytosolic glutathione or thioredoxin antioxidant defense in mouse cochlea.

The question then becomes, under G6pd deficiency conditions, which NADPHproducing enzyme can act as the major source of NADPH for the cytosolic glutathione or thioredoxin antioxidant defense in the mouse cochlea? Because there are four enzymes that produce NADPH within the cytosol (G6PD, 6PGD, ME1, and IDH1), we investigated the effects of G6pd deficiency on the NADPH redox state and the activities G6PD, 6PGD, ME1, and IDH1 in the cytosol of the inner ears. First, we confirmed that young $G 6 p d^{-/ y}$ mice displayed an $80 \%$ decrease in G6PD activities in the cytosol of the inner ears (Fig. $8 a$ ). However, contrary to our expectations, there were no differences in the levels of $\mathrm{NADPH}$ or $\mathrm{NADP}^{+}$, or NADPH/total NADP $\left(\mathrm{NADPH}+\mathrm{NADP}^{+}\right)$ratios between young $G 6 p d^{+/ \mathrm{y}}$ and $G 6 p d^{-/ y}$ mice (Fig. $8 b-d$ ), indicating that G6pd deficiency does not affect or decrease the cytosolic NADPH redox state in mouse cochlea. Next, we measured the activities and protein levels of cytosolic 6PGD, ME1, and IDH1 in the inner ears from young $G 6 p d^{+/ y}$ and G6pd $d^{-/ y}$ mice. Interestingly, G6pd deficiency increased the activities and protein levels of IDH1 (Fig. 8i,j), but not 6PGD or ME1 in the cytosol of the inner ears (Fig. $8 e-h$ ). To further investigate whether IDH1 is the major source of NADPH for cellular survival, we measured cell growth rates in the mouse inner ear HEI-OC1 cell lines that were transfected with siRNA targeted to mouse G6pd or Idh1. First, we confirmed that siRNAmediated knockdown of G6pd resulted in a $72.6 \%$ decrease in protein levels in the HEI-OC1 cells (Fig. 9a), whereas siRNA- mediated knockdown of $I d h 1$ resulted in an $80.0 \%$ decrease in protein levels in the HEI-OC1 cells (Fig. 9b). Knockdown of G6pd did not affect cell growth rates after $24,48,72$, or 96 h of incubation (Fig. 9c). However, knockdown of $I d h 1$ resulted in reduced cell growth after 72 and $96 \mathrm{~h}$ compared with control cells (Fig. $9 d, e)$. We also measured the levels of NADPH and $\mathrm{NADP}^{+}$and NADPH/total NADP ratios in the cytosol of G6pd or $I d h 1$ knockdown HEI-OC1 cells. Knockdown of Idh1, but not G6pd, decreased cytosolic NADPH levels and NADPH/total NADP ratios in the HEI-OC1 cells (Fig. 9f,k). Last, we measured the activities of cytosolic GSR and TXNRD in G6pd- or Idh1-knockdown HEIOC1 cells. Although there were no differences in the activities of GSR between control, G6pd and Idh 1 knockdown HEI-OC1 cells (Fig. 9l), knockdown of $I d h 1$, but not G6pd, decreased cytosolic TXNRD activities by $37.2 \%$ in the HEI-OC1 cells (Fig. $9 \mathrm{~m}$ ). Collectively, these tissue and cell line results suggest that, under G6pd deficiency conditions, IDH1 could act as the major source of NADPH for the cytosolic antioxidant defense in cochlear tissues. 

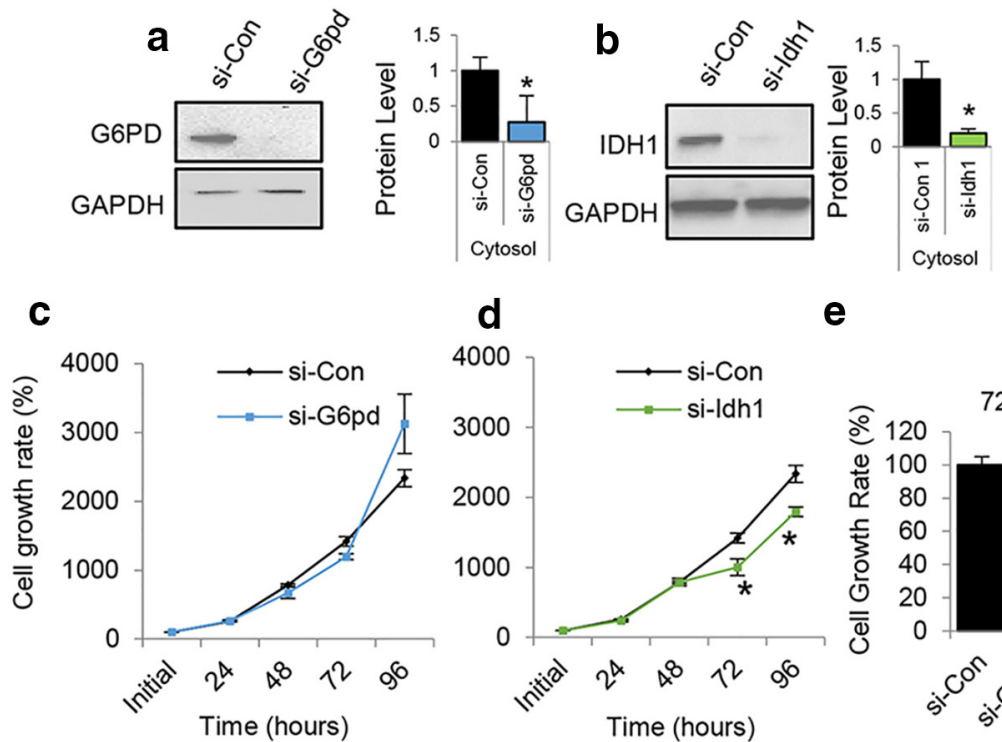

d

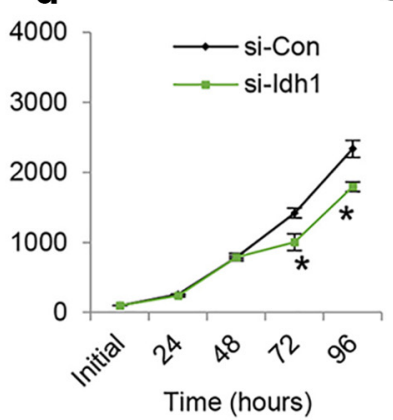

e

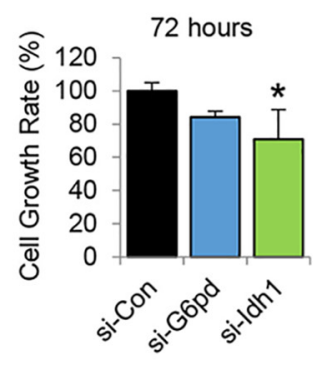

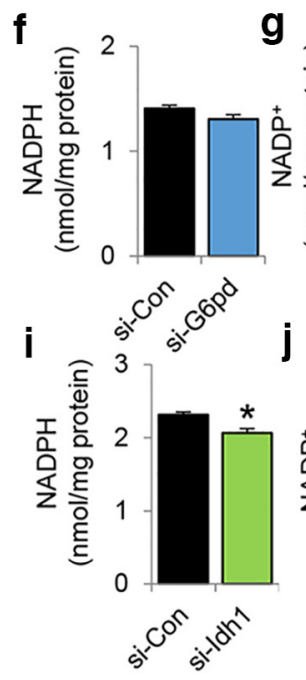

1

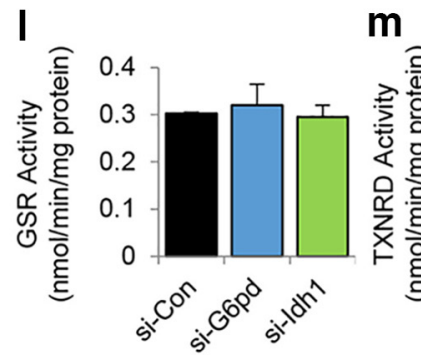

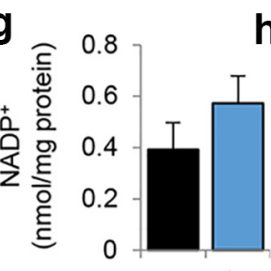

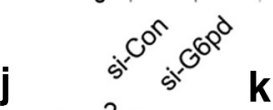
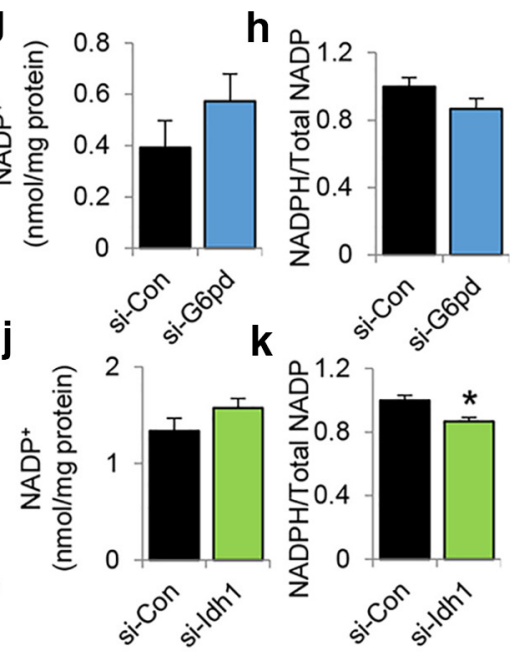

m

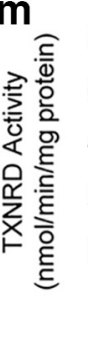

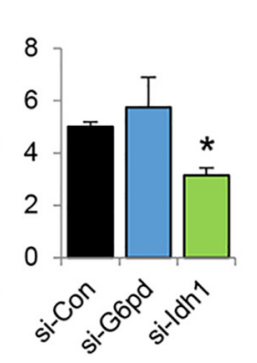

Figure 9. Assessment of cell growth, NADPH redox state, and glutathione and thioredoxin antioxidant defense in HEI-0C1 cell lines deficient for G6pd or Idh1. $\boldsymbol{a}, \boldsymbol{b}$, Western blotting analysis of G6PD protein levels ( $\boldsymbol{a}$ ) in control and G6pd knockdown HEI-OC1 cell lines. Western blotting analysis of IDH1 protein levels $(\boldsymbol{b})$ in control and Idh1 knockdown HEI-0C1 cell lines. $\boldsymbol{c}, \boldsymbol{d}$, Cell growth rates were measured in G6pd knockdown HEl-0C1 cell lines at 0, 24, 48, 72, and $96 \mathrm{~h}$ (c). Cell growth rates were measured in Idh1 knockdown HEI-0C1 cell lines at $0,24,48,72$, and $96 \mathrm{~h}(\boldsymbol{d})$. $\boldsymbol{e}-\boldsymbol{m}$, Cell growth rates $(\boldsymbol{e})$, levels of NADPH $(\boldsymbol{f}, \boldsymbol{i})$ and NADP ${ }^{+}(\boldsymbol{g}, \boldsymbol{j}), \mathrm{NADPH} /$ total NADP $(\boldsymbol{h}, \boldsymbol{k})$, and activities of GSR $(\boldsymbol{I})$ and TXNRD1 ( $\left.\boldsymbol{m}\right)$ were measured in control, G6pd-, Idh-knockdown HEl-0C1 cell lines at $72 \mathrm{~h}$. Data are mean $\pm \mathrm{SEM}(N=3) .{ }^{*} p<0.05$.

\section{Discussion}

Among the cytosolic enzymes that generate NADPH from $\mathrm{NADP}^{+}$, it is widely thought that G6PD is the principal and essential source of NADPH for the cytosolic glutathione and thioredoxin antioxidant defenses in the RBCs. It is estimated that $>400$ million people worldwide are affected by G6PD deficiency (Nkhoma et al., 2009; Stanton, 2012). Because the G6PD locus contains nearly 400 allelic variants, the variants are divided into five classes based on the phenotypic severity of the G6PD deficiency by the World Health Organization: Class 1 is classified as severe deficiency ( $<1 \%$ of WT G6PG activity); Class II is classified as severe deficiency $(<10 \%$ of WT G6PD activity); Class III is classified as mild deficiency $(10 \%-60 \%$ of WT G6PD activity); Class IV is classified as nondeficient variant $(60 \%-90 \%$ of WT G6PD activity); and Class $\mathrm{V}$ is classified as nondeficient variant, but increased activity ( $>110 \%$ of WT G6PD activity). Most G6PD-deficient individuals are Class III. In individuals with G6PD deficiency, hemolytic anemia or breakdown of RBCs is most often triggered by antimalarial drugs or viral infections due likely to increased susceptibility of the RBCs to ROS (Beutler, 1994). In agreement with those clinical reports, inhibition of G6PD leads to cardiomyocyte contractile dysfunction and decreased levels of cytosolic GSH in adult cardiomyocytes (Jain et al., 2003). Ischemia-reperfusion also impairs cardiac contractile performance in G6pd hypomorphic mice (Jain et al., 2004). Together, these reports strongly suggest that, under stress conditions, G6PD is the principal and essential source of NADPH for the cytosolic antioxidant defenses in the RBCs and hearts. However, in the current study, we unexpectedly found that G6pd deficiency did not result in decreased cytosolic NADPH redox state or decreased activities of cytosolic GSR, TXNRD, CAT, or SOD in the mouse cochlea under normal physiological conditions. In agreement with these biochemical analysis results, G6pd homozygous mice did not display increased levels of oxidative DNA or cytosolic protein damage markers compared with WT mice in the inner ears. Importantly, no histological abnormalities were observed in the IHCs, OHCs, SGNs, or SV in the cochlea of G6pd hemizygous males or G6pd homozygous females, both of which displayed normal hearing function. Therefore, contrary to our expectations, our findings suggest that, under normal physiological conditions, G6PD is not essential for the maintenance of the cytosolic NADPH redox state or the cytosolic glutathione or thioredoxin antioxidant defense in the cochlea.

We have also demonstrated that, under G6pd deficiency conditions, IDH1, but not 6PGD or ME1, could function as the major source of NADPH for the cytosolic glutathione and thioredoxin defense in mouse cochlea. Within the cytosol of a cell, $\mathrm{NADPH}$ is generated from $\mathrm{NADP}^{+}$by four enzymes: G6PD, 
6PGD, IDH1, or ME1 (Ying, 2008). 6PGD catalyzes the conversion of 6-phosphogluconate to ribulose 5-phosphate and $\mathrm{NADP}^{+}$ to NADPH in the pentose phosphate pathway. However, given that G6PD acts upstream of 6PGD and generates 6-phosphogluconate, NADPH generated by 6PGD most likely depends on G6PD activity. Hence, it is unlikely that 6PGD can function as the major source of NADPH for the cytosolic glutathione or thioredoxin antioxidant defense under G6pd deficiency conditions. ME1 catalyzes the reversible oxidative decarboxylation of malate to pyruvate and $\mathrm{NADP}^{+}$to NADPH for fatty acid biosynthesis. ME1 activity is activated by elevated levels of thyroid hormones or by higher proportions of carbohydrates in the diet. Although it has been shown that cytosolic ME2 does not play an essential role in reducing oxidative stress in Arabidopsis (Li et al., 2013), currently there is little or no information on the roles of cytosolic ME1 in the cytosolic glutathione or thioredoxin antioxidant defense in mammals. Cytosolic IDH1 catalyzes the oxidative decarboxylation of isocitrate to $\alpha$-ketoglutarate and $\mathrm{CO}_{2}$ and reduces $\mathrm{NADP}^{+}$to NADPH (Ying, 2008). IDH1 is highly expressed in the liver and involved in lipid metabolism, glucose sensing, and cytosolic antioxidant defense against ROS (Reitman et al., 2010). Park and colleagues have shown that IdhI deficiency leads to increased oxidative damage, lipid peroxidation, and intracellular peroxide generation in mouse fibroblast cell lines (Lee et al., 2002). Idh 1 deficiency also results in decreased cell viability under hydrogen peroxide treatment, whereas cells overexpressing $I d h 1$ are more resistant to hydrogen peroxide. In human melanocytes, Idh 1 knockdown decreased cell viability and increased apoptosis (Kim et al., 2012). This was associated with reduced GSH/GSSG ratios. In mouse hepatocytes, Idh 1 deficiency resulted in increased ROS levels and decreased NADPH levels compared with WT hepatocytes (Itsumi et al., 2015). In agreement with these reports, we found that G6pd deficiency increased the activities and protein levels of IDH1 (Fig. 8g,h), but not 6PGD or ME1 in the cytosol of the inner ear tissues (Fig. $8 c-f$ ). In mouse inner ear cell lines, knockdown of $I d h 1$, but not G6pd, results in reduced cell growth rates (Fig. 9d). Importantly, knockdown of Idh1, but not G6pd, decreased cytosolic NADPH levels and TXNRD activities in mouse inner ear cell lines (Fig. 9f,h). Therefore, these results and the previous reports suggest that, under G6pd deficiency conditions, IDH1, but not 6PGD or ME1, could act as the major source of NADPH for the cytosolic antioxidant defense in cochlear tissues. In summary, under normal physiological conditions, it is likely that G6PD is not essential for the maintenance of the cytosolic glutathione or thioredoxin antioxidant defense in the cochlea. However, under high levels of oxidative stress or on other genetic backgrounds, such as the C57BL/6 strain that is homozygous for the recessive AHLsusceptibility allele $C d h 23^{753 \mathrm{~A}}$, we speculate that G6pd deficiency may result in increased oxidative damage in the HCs or SGNs of the cochlea.

Note Added in Proof: The first author's name, Karessa White, was accidentally incorrectly listed in the Early Release version published 4 May 2017. The author's name has now been corrected.

\section{References}

Beutler E (1994) G6PD deficiency. Blood 84:3613-3636. Medline

Calabrese V, Cornelius C, Maiolino L, Luca M, Chiaramonte R, Toscano MA, Serra A (2010) Oxidative stress, redox homeostasis and cellular stress response in Meniere's disease: role of vitagenes. Neurochem Res 35:22082217. CrossRef Medline

Cappellini MD, Fiorelli G (2008) Glucose-6-phosphate dehydrogenase deficiency. Lancet 371:64-74. CrossRef Medline
Chen GD, Decker B, Krishnan Muthaiah VP, Sheppard A, Salvi R (2014) Prolonged noise exposure-induced auditory threshold shifts in rats. Hear Res 317:1-8. CrossRef Medline

Deponte M (2013) Glutathione catalysis and the reaction mechanisms of glutathione-dependent enzymes. Biochim Biophys Acta 1830:3217-3266. CrossRef Medline

Ding D, Li M, Zheng X, Wang J, Salvi RJ (1999) [Cochleogram for assessing hair cells and efferent fibers in carboplatin-treated ear]. Lin Chuang Er Bi Yan Hou Ke Za Zhi 13:510-512. Medline

Ding D, Qi W, Yu D, Jiang H, Han C, Kim MJ, Katsuno K, Hsieh YH, Miyakawa T, Salvi R, Tanokura M, Someya S (2013) Addition of exogenous $\mathrm{NAD}^{+}$prevents mefloquine-induced neuroaxonal and hair cell degeneration through reduction of caspase-3-mediated apoptosis in cochlear organotypic cultures. PLoS One 8:e79817. CrossRef Medline

Ding D, Jiang H, Chen GD, Longo-Guess C, Muthaiah VP, Tian C, Sheppard A, Salvi R, Johnson KR (2016) N-acetyl-cysteine prevents agerelated hearing loss and the progressive loss of inner hair cells in $\gamma$-glutamyl transferase 1 deficient mice. Aging 8:730-750. CrossRef Medline

Evans P, Halliwell B (1999) Free radicals and hearing: cause, consequence, and criteria. Ann N Y Acad Sci 884:19-40. CrossRef Medline

Han C, Ding D, Lopez MC, Manohar S, Zhang Y, Kim MJ, Park HJ, White K, Kim YH, Linser P, Tanokura M, Leeuwenburgh C, Baker HV, Salvi RJ, Someya S (2016) Effects of long-term exercise on age-related hearing loss in mice. J Neurosci 36:11308-11319. CrossRef Medline

Ho HY, Cheng ML, Lu FJ, Chou YH, Stern A, Liang CM, Chiu DT (2000) Enhanced oxidative stress and accelerated cellular senescence in glucose6-phosphate dehydrogenase (G6PD)-deficient human fibroblasts. Free Radic Biol Med 29:156-169. CrossRef Medline

Itsumi M, Inoue S, Elia AJ, Murakami K, Sasaki M, Lind EF, Brenner D, Harris IS, Chio II, Afzal S, Cairns RA, Cescon DW, Elford AR, Ye J, Lang PA, Li WY, Wakeham A, Duncan GS, Haight J, You-Ten A, et al. (2015) Idh1 protects murine hepatocytes from endotoxin-induced oxidative stress by regulating the intracellular NADP $(+) / \mathrm{NADPH}$ ratio. Cell Death Differ 22:1837-1845. CrossRef Medline

Jacono AA, Hu B, Kopke RD, Henderson D, Van De Water TR, Steinman HM (1998) Changes in cochlear antioxidant enzyme activity after sound conditioning and noise exposure in the chinchilla. Hear Res 117:31-38. CrossRef Medline

Jain M, Brenner DA, Cui L, Lim CC, Wang B, Pimentel DR, Koh S, Sawyer DB, Leopold JA, Handy DE, Loscalzo J, Apstein CS, Liao R (2003) Glucose-6-phosphate dehydrogenase modulates cytosolic redox status and contractile phenotype in adult cardiomyocytes. Circ Res 93:e9-e16. CrossRef Medline

Jain M, Cui L, Brenner DA, Wang B, Handy DE, Leopold JA, Loscalzo J, Apstein CS,Liao R (2004) Increased myocardial dysfunction after ischemia-reperfusion in mice lacking glucose-6-phosphate dehydrogenase. Circulation 109: 898-903. Medline

Kalinec GM, Webster P, Lim DJ, Kalinec F (2003) A cochlear cell line as an in vitro system for drug ototoxicity screening. Audiol Neurotol 8:177189. CrossRef Medline

Kamerbeek NM, van Zwieten R, de Boer M, Morren G, Vuil H, Bannink N, Lincke C, Dolman KM, Becker K, Schirmer RH, Gromer S, Roos D (2007) Molecular basis of glutathione reductase deficiency in human blood cells. Blood 109:3560-3566. CrossRef Medline

Kim JY, Shin JY, Kim M, Hann SK, Oh SH (2012) Expression of cytosolic $\mathrm{NADP}(+)$-dependent isocitrate dehydrogenase in melanocytes and its role as an antioxidant. J Dermatol Sci 65:118-125. CrossRef Medline

Kirkman HN, Gaetani GF (2007) Mammalian catalase: a venerable enzyme with new mysteries. Trends Biochem Sci 32:44-50. CrossRef Medline

Kornberg A (1955) Isocitrate dehydrogenase of yeast (DPN). Methods Enzymol 1:707-709. CrossRef

Lee CY, Lee SM, Lewis S, Johnson FM (1980) Identification and biochemical analysis of mouse mutants deficient in cytoplasmic malic enzyme. Biochemistry 19:5098-5103. CrossRef Medline

Lee SM, Koh HJ, Park DC, Song BJ, Huh TL, Park JW (2002) Cytosolic $\operatorname{NADP}(+)$-dependent isocitrate dehydrogenase status modulates oxidative damage to cells. Free Radic Biol Med 32:1185-1196. CrossRef Medline

Li S, Mhamdi A, Clement C, Jolivet Y, Noctor G (2013) Analysis of knockout mutants suggests that Arabidopsis NADP-MALIC ENZYME2 does 
not play an essential role in responses to oxidative stress of intracellular or extracellular origin. J Exp Bot 64:3605-3614. CrossRef Medline

Minucci A, Giardina B, Zuppi C, Capoluongo E (2009) Glucose-6-phosphate dehydrogenase laboratory assay: how, when, and why? IUBMB Life 61: 27-34. CrossRef Medline

Müller M, von Hünerbein K, Hoidis S, Smolders JW (2005) A physiological place-frequency map of the cochlea in the CBA/J mouse. Hear Res 202: 63-73. CrossRef Medline

Nicol CJ, Zielenski J, Tsui L C, Wells PG (2000) An embryoprotective role for glucose-6-phosphate dehydrogenase in developmental oxidative stress and chemical teratogenesis. FASEB J 14:111-127.

Nkhoma ET, Poole C, Vannappagari V, Hall SA, Beutler E (2009) The global prevalence of glucose-6-phosphate dehydrogenase deficiency: a systematic review and meta-analysis. Blood Cells Mol Dis 42:267-278. Medline

Noben-Trauth K, Zheng QY, Johnson KR (2003) Association of cadherin 23 with polygenic inheritance and genetic modification of sensorineural hearing loss. Nat Genet 35:21-23. CrossRef Medline

Ohlemiller KK, McFadden SL, Ding DL, Lear PM, Ho YS (2000) Targeted mutation of the gene for cellular glutathione peroxidase (Gpx1) increases noise-induced hearing loss in mice. J Assoc Res Otolaryngol 1:243-254. CrossRef Medline

Rahman I, Kode A, Biswas SK (2006) Assay for quantitative determination of glutathione and glutathione disulfide levels using enzymatic recycling method. Nat Protoc 1:3159-3165. CrossRef Medline

Reitman ZJ, Yan H (2010) Isocitrate dehydrogenase 1 and 2 mutations in cancer: alterations at a crossroads of cellular metabolism. J Natl Cancer Inst 102:932-941. CrossRef Medline

Repetto G, del Peso A, Zurita JL (2008) Neutral red uptake assay for the estimation of cell viability/cytotoxicity. Nat Protoc 3:1125-1131. CrossRef Medline

Riganti C, Gazzano E, Polimeni M, Aldieri E, Ghigo D (2012) The pentose phosphate pathway: an antioxidant defense and a crossroad in tumor cell fate. Free Radic Biol Med 53:421-436. CrossRef Medline

Sanders S, Smith DP, Thomas GA, Williams ED (1997) A glucose-6phosphate dehydrogenase (G6PD) splice site consensus sequence muta- tion associated with G6PD enzyme deficiency. Mutat Res 374:79-87. CrossRef Medline

Shan C, Elf S, Ji Q, Kang HB, Zhou L, Hitosugi T, Jin L, Lin R, Zhang L, Seo JH, Xie J, Tucker M, Gu TL, Sudderth J, Jiang L, DeBerardinis RJ, Wu S, Li Y, Mao H, Chen PR, et al. (2014) Lysine acetylation activates 6-phosphogluconate dehydrogenase to promote tumor growth. Mol Cell 55:552-565. CrossRef Medline

Someya S, Xu J, Kondo K, Ding D, Salvi RJ, Yamasoba T, Rabinovitch PS, Weindruch R, Leeuwenburgh C, Tanokura M, Prolla TA (2009) Agerelated hearing loss in $\mathrm{C} 57 \mathrm{BL} / 6 \mathrm{~J}$ mice is mediated by Bak-dependent mitochondrial apoptosis. Proc Natl Acad Sci U S A 106:19432-19437. CrossRef Medline

Someya S, Yu W, Hallows WC, Xu J, Vann JM, Leeuwenburgh C, Tanokura M, Denu JM, Prolla TA (2010) Sirt3 mediates reduction of oxidative damage and prevention of age-related hearing loss under caloric restriction. Cell 143:802-812. CrossRef Medline

Stanton RC (2012) Glucose-6-phosphate dehydrogenase, NADPH, and cell survival. IUBMB life 64:362-369. CrossRef Medline

Worley G, Erwin CW, Goldstein RF, Provenzale JM, Ware RE (1996) Delayed development of sensorineural hearing loss after neonatal hyperbilirubinemia: a case report with brain magnetic resonance imaging. Dev Med Child Neurol 38:271-277. CrossRef Medline

Xu Y, Zhang Z, Hu J, Stillman IE, Leopold JA, Handy DE, Loscalzo J,Stanton RC (2010) Glucose-6-phosphate dehydrogenase-deficient mice have increased renal oxidative stress and increased albuminuria. FASEB J 24: 609-616. CrossRef Medline

Ying $\mathrm{W}(2008) \mathrm{NAD}^{+} / \mathrm{NADH}$ and $\mathrm{NADP}^{+} / \mathrm{NADPH}$ in cellular functions and cell death: regulation and biological consequences. Antioxid Redox Signal 10:179-206. CrossRef Medline

Zerez CR, Lee SJ, Tanaka KR (1987) Spectrophotometric determination of oxidized and reduced pyridine nucleotides in erythrocytes using a single extraction procedure. Anal Biochem 164:367-373. CrossRef Medline

Zheng QY, Johnson KR, Erway LC (1999) Assessment of hearing in 80 inbred strains of mice by ABR threshold analyses. Hear Res 130:94-107. CrossRef Medline 